\title{
THE TECHNOSTRESS TRIFECTA - TECHNO EUSTRESS, TECHNO- DISTRESS AND DESIGN: AN AGENDA FOR RESEARCH
}

\begin{abstract}
Technostress - defined as stress that individuals experience due to their use of Information Systems - represents an emerging phenomenon of scholarly investigation. It examines how and why the use of IS causes individuals to experience various demands that they find stressful. This paper develops a framework for guiding future research in technostress experienced by individuals in organizations. We first review and critically analyze the state of current research on technostress reported in journals from the IS discipline and the non-IS disciplines that study stress in organizations (e.g. organizational behaviour and psychological stress). We then develop our framework in the form of the 'Technostress Trifecta' - technoeustress, techno-distress and Information Systems design principles for technostress. The paper challenges three key ideas imbued in the existing technostress literature. First, it develops the argument that, in contrast to negative outcomes, technostress can lead to positive outcomes such as greater effectiveness and innovation at work. Second, it suggests that instead of limiting the role of IS to that of being a stress creator in the technostress phenomenon, it should be expanded to that of enhancing the positive and mitigating the negative effects of technostress through appropriate design. Third, it lays the groundwork for guiding future research in technostress through an inter-disciplinary framing that enriches both the IS and the psychological stress literatures through a potential discourse of disciplinary exchange.
\end{abstract}

Keywords: Technostress, Techno-Eustress, Techno-Distress, Organizational Stress, Psychological Stress, IS Design, Inter-disciplinary, Cross-Disciplinary. 
'.... not afraid to enjoy the stress of a full life, nor too naïve to think they can do so without intellectual effort' - Hans Selye (1956)

\section{INTRODUCTION}

Technostress - defined as stress that individuals experience due to their use of Information Systems (IS) - represents an emerging area of scholarly investigation in IS (e.g. Ragu-Nathan et al. 2008; Ayyagari et al. 2011). Stress embodies the condition of imbalance experienced by an individual between the demands of a given situation and his or her ability to meet them (e.g. McGrath 1976; Cooper et al. 2001). The phenomenon of technostress investigates how and why the use of IS causes various demands on the individual. It finds wide-ranging practice and policy related relevance as evidenced by mention in practitioner writing $^{1}$ and legislation ${ }^{2}$. It is a relatively young phenomenon from the scholarly point of view and the IS literature on technostress is fairly nascent in that scholarly empirical work was first reported in a mainstream IS journal about ten years ago (Tarafdar et al. 2007). Further, it is interdisciplinary in nature because it embodies 'complementarity' (Orlikowski and Barley 2001) and a theoretical link between the literatures of IS and psychological stress. It is also a continually evolving phenomenon as new types of IS (that include new devices and applications) and their use persistently emerge and reveal novel aspects of it.

As currently comprised, the literature on technostress focuses on demands relating to the use of IS that the individual finds unable to meet and that lead to adverse consequences. It conceptualizes the use of IS as a stress creator. However, we are beginning to see both scholarly (e.g. Ohly and Latour 2014) and practice-based accounts (e.g. Eurofound and the International Labour Office, 2017) of how the very characteristics of IS such as constant connectivity and ubiquity that are associated with technostress creating conditions and their negative outcomes, can also challenge individuals to harness them for positive consequences such as greater work flexibility. We also note the emergence of 'digital detox' applications and 'email assistants' (Kokkalis et al 2013) ${ }^{3}$ wherein the use of particular IS can help individuals deal with technostress creating conditions such as technology related invasion and overload. These sorts of examples suggest that technostress is an embodiment of a theoretically more nuanced and 'messy' (Lundberg and Cooper 2011) relationship between

\footnotetext{
${ }^{1}$ See for example http://www.bbc.co.uk/news/business-36517644 and https://www.salon.com/2016/05/30/plugged in and stressed_out technology is killing the work life balanc $\mathrm{e} /$

${ }^{\frac{2}{2}}$ See for example http://money.cnn.com/2017/01/02/technology/france-office-email-workers-law/

${ }^{3}$ See for example http://www.telegraph.co.uk/technology/0/digital-detox-easy-ways-to-take-yourself-offline/
} 
IS use and well-being than what current literature indicates. Although the literature shows evidence of accumulating many concepts and relationships, it does not address these emerging developments. Similarly, the psychological stress literature while acknowledging that technology can be a source of stress (e.g. Barber and Santuzzi 2015), has not theoretically developed the link between stress and technology.

Emerging literatures that focus on complex, interdisciplinary and evolving phenomenon can benefit from exposure to foundational theoretical concepts and structure early on, as guidance for coherent development going forward (Webster and Watson 2004). The primary objective of this paper is thus to develop a framework for guiding future research on the phenomenon of technostress experienced by individuals in organizations. We believe that such an effort would be valuable for the development of the technostress literature for the following reasons. First it would provide a foundation for theoretically reframing and extending the current ambit of its conceptualization to take into account emerging developments. Second it would serve to identify and integrate conceptual themes and relationships constituting the phenomenon, thus developing a theoretically rigorous framing through which future scholarly efforts can be directed. Third it would articulate how the IS literatures on technostress and the non-IS literatures that study psychological stress can mutually enrich and inform one another.

In order to do this, it is necessary to understand the current theoretical expositions of technostress. A secondary objective is therefore to conduct a review of the literature and critically analyze the state of current research on technostress.

In laying out directions for future research, the paper challenges current ideas in the technostress literature in three ways. First, it develops the argument that, in contrast to the much examined negative outcomes, technostress can be harnessed as motivation for positive outcomes such as greater effectiveness and innovation at work. Second, it suggests that in addition to being a stress creator, the role of IS in the technostress phenomenon should be expanded to that of enhancing the positive and mitigating the negative effects of technostress through appropriate design. Third, it lays the groundwork for guiding future research in technostress through an interdisciplinary framing that enriches both the IS and the psychological stress literatures through a discourse of disciplinary exchange.

In Sections 2 and 3, we provide background on and review the literature in technostress. In Section 4 we analyze its key themes, and identify less-understood and underresearched, yet relevant aspects. Section 5 presents our framework for future research and identifies research questions, in the form of the 'Technostress Trifecta' that constitutes 
techno-eustress, techno-distress, and IS design for tackling technostress. Section 6 presents discussions and concluding comments.

\section{THEORETICAL BACKGROUND}

Early scholarly approaches considered the term 'stress' as either a 'response' or a 'stimulus'. The response-based approach focused on a medical/physiological perspective (McGrath 1976; Selye 1956). It viewed stress as a dependent variable, usually a medical or physiological condition of the individual. Disturbing stimuli, usually difficult life situations were considered the causal, independent variables. The stimulus-based approach (Goodell et al. 1986) had its basis in engineering and physical sciences. It considered stress as an independent variable, a force exerted on an individual, which resulted in a negative reaction. The shortcomings of these approaches were that they (Cooper et al 2001): (1) focused on either the stimulus or response, but did not explain how and why one led to the other; (2) ignored the importance of the individual and the individual differences in the perceptual and cognitive processes underpinning these relationships; and (3) did not consider why the individual perceived a situation as stressful and what they could do to deal with. Hence they are conceptually limited and inadequate for explaining stress experienced by users in organizations, a more complex psychological phenomenon, wherein individuals subjectively react differently to different situations, experience different forms of disturbances, and exhibit different manifestations of their experience of stress (e.g. Cooper et al. 2001; Cooper and Dewe 2004; Lazarus and Folkman 1984; Pearlin et al. 1981).

To reflect these realities, theories that study psychological stress have embodied a processual approach, where the phenomenon of stress is seen as a process that involves a transaction between the individual and the environment. Stress is neither in the individual (i.e. the response), nor in the environment (i.e. the force), but an ongoing process of individuals transacting with their environments. Stress is a process that includes: (1) the presence of environmental condition; which the individual appraises as a (2) demand or stressor that is significantly taxing on his or her resources; which sets into motion (3) coping responses; that lead to (4) psychological, behavioral and physiological outcomes experienced by the individual. Described in various seminal texts under the overall theoretical framing of the Transactional Theory of Stress (e.g. Cooper et al. 2001; Folkman 2011; Kahn and Byosiere 1992; Lazarus 1966; Lazarus and Folkman 1984; McGrath 1976), such a framing has provided a widely adopted foundation for understanding stress experienced by 
individuals in organizations, most notably because it addresses the complex and messy nature of how the phenomenon of psychological stress unfolds ${ }^{4}$.

The stress process provides a conceptual starting point for understanding technostress. Accordingly, the phenomenon of technostress, which addresses the context in which the stress process is activated due to the use of IS, has been conceptualized over the course of multiple studies, in this framing, as a process (e.g. Ayyagari et al. 2011; D'Arcy et al 2014; Galluch et al 2015; Ragu-Nathan et al. 2008) ${ }^{5}$. Technostress is a process that includes: (1) the presence of technology environmental conditions; which are appraised as (2) demands or techno-stressors that are taxing on the individual and require a change; which set into motion (3) coping responses; that lead to (4) psychological, physical and behavioural outcomes for the individual. Primary appraisal focuses on the individual's assessment of the extent of demand and influences the relationship between technology environmental conditions and techno-stressors. Secondary appraisal secondary appraisal focuses on the individual's evaluation of availability of options and resources in order to respond to the stressful situation. It influences the relationship between the techno-stressors and coping responses.

\section{LITERATURE REVIEW}

To understand which aspects of this process have been studied, we conducted a literature review of relevant papers from a number of different disciplines where either technostress or the technology related aspects of stress in general have been studied. These include the IS discipline, and the non-IS disciplines of organizational behavior, psychological stress, and other cognate disciplines where workplace stress has been studied. The literature review included the following considerations - (1) selection of disciplinary corpus, keywords and journals; (2) article selection through initial query run and backward and forward search; (3) article classification. These steps are presented in detail in Appendices A, B and C. To describe here briefly, for each discipline, we selected the set of leading journals and searched for relevant keywords in titles, abstracts and keywords of all articles published since 1995, to generate an approximately 20 year (1995-2016) horizon for our search. The starting year of

\footnotetext{
${ }^{4}$ The word 'stress' is perhaps one of the most used, in an everyday and layman sense, and in that context, has several dictionary meanings attributed to it, such as 'reaction' or 'force' or 'fatigue' (see Sutherland and Cooper 1990). In this paper we do not consider the everyday definition, which is not within the purview of our study. We focus on the scholarly meaning and definition of stress as a psychological phenomenon of study that includes a number of variables and their relationships (See Lazarus 1966).

${ }^{5}$ Empirical examination of these relationships has largely been through variance based approaches (e.g. survey and experiments), as we later show in Appendix C.
} 
1995 is prior to the uptake of pervasive, mobile, multi-device and multi-application use of IS, which are key drivers of technostress. A total of 182 articles were retrieved and analysed, to ultimately select 27 articles. We find that the articles covered the following aspects of technostress: Technology Environmental Conditions, Techno-Stressors, Coping Responses, Outcomes, and Moderators of stressor-outcome relationship. Table 1 tabulates and describes each concept, as it emerged collectively from the papers in our corpus that covered it. We describe them next.

Table 1. Literature Review

\begin{tabular}{|c|c|c|c|}
\hline Concept & Definition & Details & References \\
\hline $\begin{array}{l}\text { Technology } \\
\text { environmental } \\
\text { conditions }\end{array}$ & $\begin{array}{l}\text { Characteristics of IS } \\
\text { used by individuals in } \\
\text { the organization that } \\
\text { have the potential to } \\
\text { create a demand in } \\
\text { the individual }\end{array}$ & $\begin{array}{l}\text { Ubiquity, Reliability, Ease of } \\
\text { use, Mobility, Presenteeism, } \\
\text { Technology created } \\
\text { interruptions }\end{array}$ & Ayyagari et al. 2011 \\
\hline \multirow{15}{*}{$\begin{array}{l}\text { Techno- } \\
\text { Stressor }\end{array}$} & \multirow{10}{*}{$\begin{array}{l}\text { IS stress creators } \\
\text { appraised by the } \\
\text { individual as } \\
\text { threatening }\end{array}$} & \multirow{10}{*}{$\begin{array}{l}\text { Techno-insecurity, Techno- } \\
\text { overload, Techno-invasion, } \\
\text { Techno-uncertainty, Techno- } \\
\text { complexity }\end{array}$} & Barber and Santuzzi 2015 \\
\hline & & & Barley et al. 2011 \\
\hline & & & D’Arcy et al. 2014 \\
\hline & & & Day et al. 2012 \\
\hline & & & Galluch et al. 2015 \\
\hline & & & $\begin{array}{l}\text { Reinke and Chamorro- } \\
\text { Premuzic } 2014\end{array}$ \\
\hline & & & Maier et al. 2014, 2015 \\
\hline & & & Sprigg and Jackson 2006 \\
\hline & & & Tarafdar et al. 2007 \\
\hline & & & Zhang et al. 2016 \\
\hline & \multirow{5}{*}{$\begin{array}{l}\text { Factors affecting the } \\
\text { level of techno- } \\
\text { stressors }\end{array}$} & \multirow{5}{*}{$\begin{array}{l}\text { Attitude towards IS, } \\
\text { workload, work complexity, } \\
\text { digital literacy and user } \\
\text { involvement }\end{array}$} & Barber and Santuzzi 2015 \\
\hline & & & Barley et al. 2011 \\
\hline & & & Chen et al. 2009 \\
\hline & & & Korunka and Vitouch 1999 \\
\hline & & & Tarafdar et al. 2010 \\
\hline \multirow{5}{*}{$\begin{array}{l}\text { Outcomes } \\
\text { (also referred } \\
\text { to as 'Strain') }\end{array}$} & \multirow{5}{*}{$\begin{array}{l}\text { Non-beneficial or } \\
\text { adverse } \\
\text { consequences } \\
\text { emanating from a } \\
\text { direct relationship }\end{array}$} & \multirow{5}{*}{$\begin{array}{l}\text { Job-related negative } \\
\text { outcomes }\end{array}$} & Tarafdar et al. 2007 \\
\hline & & & Ragu-Nathan et al. 2008 \\
\hline & & & Sprigg and Jackson 2006 \\
\hline & & & Barber and Santuzzi 2015 \\
\hline & & & Tarafdar et al 2015 \\
\hline
\end{tabular}




\begin{tabular}{|c|c|c|c|}
\hline & with the various & & D'Arcy et al. 2014 \\
\hline & techno-stressors & IS use related negative & Maier et al. 2014,2015 \\
\hline & & outcomes & Tarafdar et al. 2010 \\
\hline & & & Zhang et al. 2016 \\
\hline & & & Aiello and Kolb 1995 \\
\hline & & & Ayyagari et al. 2011 \\
\hline & & & Barber and Santuzzi 2015 \\
\hline & & & Barley et al. 2011 \\
\hline & & & Brown et al. 2014 \\
\hline & & & Chen et al. 2009 \\
\hline & & Well-being related negative & Day et al. 2012 \\
\hline & & outcomes - feeling burned & Galluch et al. 2015 \\
\hline & & out, drained etc. & Korunka and Vitouch 1999 \\
\hline & & & Maier et al. 2015 \\
\hline & & & $\begin{array}{l}\text { Reinke and Chamorro- } \\
\text { Premuzic } 2014\end{array}$ \\
\hline & & & Srivastava et al. 2015 \\
\hline & & & Sykes 2015 \\
\hline & & & Zhang et al. 2016 \\
\hline & & & Galluch et al. 2015 \\
\hline & & Physiological outcomes, e.g. & Tams et al. 2014 \\
\hline & & siress normones & Day et al. 2012 \\
\hline & & & Fuglseth and Sørebø 2014 \\
\hline & & & Ragu-Nathan et al. 2008 \\
\hline & & Factors decreasing the level & Soucek and Moser 2010 \\
\hline & & & Sykes 2015 \\
\hline & & & Yan et al. 2013 \\
\hline Coping & $\begin{array}{l}\text { In response to IS } \\
\text { security related } \\
\text { techno-stressors }\end{array}$ & $\begin{array}{l}\text { Disengagement with IS } \\
\text { security requirements }\end{array}$ & D'Arcy et al. 2014 \\
\hline Response & $\begin{array}{l}\text { In response to } \\
\text { implementation/use } \\
\text { of an application }\end{array}$ & $\begin{array}{l}\text { Adaptation of IS use, } \\
\text { Negative emotions }\end{array}$ & $\begin{array}{l}\text { Beaudry and Pinsonneault } \\
\text { 2005, Ortiz de Guinea } 2016\end{array}$ \\
\hline $\begin{array}{l}\text { Moderators of } \\
\text { the stressor- } \\
\text { outcome } \\
\text { relationship }\end{array}$ & $\begin{array}{l}\text { Factors influencing } \\
\text { the relationship } \\
\text { between techno- } \\
\text { stressors and } \\
\text { outcomes }\end{array}$ & $\begin{array}{l}\text { Technology self-efficacy, } \\
\text { technology competence, } \\
\text { neuroticism, agreeableness, } \\
\text { extraversion, control over } \\
\text { access to task related } \\
\text { information, opportunity for }\end{array}$ & $\begin{array}{l}\text { Soucek and Moser } 2010 \text {, } \\
\text { Galluch et al. 2015, Srivastava } \\
\text { et al. 2015, Tarafdar et al. } \\
2015\end{array}$ \\
\hline
\end{tabular}




\begin{tabular}{|l|l|l|l|}
\hline & taking a break & \\
\hline
\end{tabular}

Technology environmental conditions: These are characteristics of IS that have the potential to create a demand in the individual - namely, ubiquity, reliability, ease of use, mobility and presenteeism. They also include IS related events such as system breakdown and technology created interruptions (Ayyagari et al. 2011; Galluch et al. 2015).

Techno-Stressors: These are stressors appraised by the individual as damaging. Overload from the use of IS, techno-overload, forces the user to do more in order to use the technology (Reinke and Chamorro-Premuzic 2014; Tarafdar et al. 2007), to adhere to extra organizational security requirements regarding its use (D'Arcy et al. 2014), to attend to expectations of others when using applications such as social media (Maier et al. 2014) or to deal with excess information and features (Zhang et al. 2016). Techno-invasion is the stressor where the user feels non-work time to be invaded by work demands (Tarafdar et al. 2007), is faced with expectations of constant availability and immediate response, and has privacy invaded by surveillance and monitoring (Barber and Santuzzi 2015; Day et al. 2012; Sprigg and Jackson 2006). Individuals experience techno-uncertainty as a stressor when they feel that IS change quickly (Tarafdar et al. 2007; Maier et al 2015), important technology related decisions are not communicated to them (Barber and Santuzzi 2015; Day et al. 2012), and they do not have control over IS use policies around, for instance, IS security (D'Arcy et al. 2014). Techno-insecurity embodies the feeling of insecurity that individuals face when they feel that others may know more about new technologies than they do (Tarafdar et al. 2007). Techno-complexity is the stressor that individuals experience because they have to constantly learn how to use IS (Barber and Santuzzi 2015; Barley et al. 2011; Day et al. 2012; Sprigg and Jackson 2006; Tarafdar et al. 2007), find it difficult to understand IS use policies (D'Arcy et al. 2014) or may be faced with too many interruptions, complications and hassles in using IS (Barber and Santuzzi 2015; Galluch et al. 2015). Factors that affect the level of techno-stressors include the attitude of the individual's towards IS (Barley et al. 2011), workload, work complexity, digital literacy and user involvement (Barber and Santuzzi 2015; Chen et al. 2009; Korunka and Vitouch 1999; Tarafdar et al. 2010, 2015).

Outcomes: Outcomes have been studied as non-beneficial or adverse consequences emanating from a direct relationship with the various techno-stressors. They have also been referred to as 'strain'. Job related outcomes include lack of job satisfaction and organizational commitment, turnover intentions, role overload, role conflict (Ragu-Nathan et al. 2008; 
Tarafdar et al. 2007), job-related anxiety and depression (Sprigg and Jackson, 2006). Outcomes relating to use of IS include lack of IS-enabled innovation and productivity, low end user satisfaction (Tarafdar et al. 2010, 2015; Zhang et al. 2016) resigned or unwilling compliance with use requirements such as quick response to email (Barber and Santuzzi 2015), and non-adherence to IS use requirements (D'Arcy et al. 2014). Well-being related outcomes include exhaustion, burnout and strain (Aiello and Kolb 1995; Ayyagari et al. 2011; Barber and Santuzzi 2015; Barley et al. 2011; Brown et al. 2014; Chen et al. 2009; Day et al. 2012; Galluch et al. 2015; Korunka \& Vitouch 1999; Maier et al 2015; Reinke and Chamorro-Premuzic, 2014; Srivastava et al. 2015; Sykes 2015; Zhang et al. 2016). Physiological outcomes include the incidence of stress hormones such as alpha amylase (Galluch et al. 2015; Tams et al. 2014).

Factors that decrease or inhibit the extent of these negative outcomes include IS management mechanisms such as literacy facilitation, technical support, end user involvement, innovation support, co-worker support and support manuals (Day et al. 2012; Fuglseth and Sørebø 2014; Ragu-Nathan et al. 2008; Soucek and Moser 2010; Sykes 2015; Yan et al. 2013).

Coping Responses: Coping behavior in response to organizational IS security related techno-stressors includes disengagement with IS use requirements (D'Arcy et al. 2014). Coping responses in response to the organizational implementation of an application include adaptation of IS use by individuals (Beaudry and Pinsonneault 2005) and negative emotions (Ortiz de Guinea, 2016).

Moderators of the techno-stressor - outcome relationship: We find factors that moderate the relationship between techno-stressors and adverse outcomes. Negative moderators include the individual's technology self-efficacy, technology competence (Tarafdar et al. 2015) and positive moderators include the personality orientations of neuroticism, agreeableness, and extraversion (Srivastava et al. 2015). The individual's control over whether he or she can access information relating to a task or take a break from the task has both positive and negative moderating effects (Galluch et al. 2015).

\section{ANALYSIS OF THE LITERATURE}

We analyse in this section, the key aspects of the literature that reports on technostress.

Technostress as a dark side phenomenon: The overarching and exclusive premise of the literature regarding technostress is that of a phenomenon associated with negative 
consequences. The literature explains only how demands from the technology environmental conditions are appraised as stressful in a threatening and negative way. The techno-stressors are appraisals of the technology environment as threatening and the outcomes examined are adverse consequences.

However, not all stressors are detrimental to the individual. In addition to presenting difficulties and threats, stressors can also enthuse and encourage individuals in positive ways. There is a distinct qualitative difference between the stress associated with creative involvement, for instance, and that associated with excessive workload (Selye 1974). The second can be damaging when the individual feels threatened because of an inability to handle it, and the first can be stimulating when it challenges the individual in a positive way. The first signifies motivation and a 'hunger for achievement' (Selye 1974, p. 82), and the second damage and inability. Stress is therefore a dual-hued phenomenon and individuals can thus appraise environmental conditions as both threatening and challenging; the respective outcomes can be damaging and beneficial respectively (e.g. Lazarus 1966).

The notions of 'Eustress' and 'Distress' describe these two distinct scenarios associated with stress (Selye 1974). Eustress is broadly referred to as stress that creates a challenge or an opportunity, and distress as stress that creates a threat or hindrance. Based on various studies, it can be suggested that distress is associated with a negative appraisal of demands in the environment that have the potential to thwart attainment of positive objectives and goals. Eustress constitutes a positive appraisal of demands in the environment that have the potential to promote personal growth and gain (Cavanaugh et al 2000; Cooper et al 2001; Crawford et al 2010; Fay et al 1998; Le Fevre et al 2003). The implementation of a new system, for instance, can be appraised as a threat or as an opportunity, upon which different kinds of adaptation behaviors are engaged in, leading to different kinds of outcomes (Beaudry and Pinsonneault 2005).

However, the technostress literature has focused on the distress aspect of stress and does not explain how the demands from the technology environment can be appraised as challenging and motivating, leading to potentially positive outcomes. As reinforcement of the practical relevance of this literature gap, we are beginning to see employees responding to IS characteristics such as reliability, ubiquity and mobility, by challenging themselves to leverage these for greater work flexibility ${ }^{6}$. There is a need for IS research to examine and explain the positive facet of technostress.

\footnotetext{
${ }^{6}$ See for example - http://destinationinnovation.economist.com/2016/12/06/technology-wellbeing-and-work/
} 
IS use as a cause of technostress: The literature considers the use of IS as triggers and causes that set in motion the process of technostress. Yet, we see are beginning to see instances in practice, of IS applications such as 'email personal assistants' that prioritize email (e.g. Kokkalis et al. 2013) and machine learning algorithms that filter spam email (Guzella \& Caminhas, 2009). Such applications can potentially help people deal with technostressors such as techno-overload. However, we did not find a single study in our literature review where the role of IS in helping to mitigate negative outcomes from technostress was examined. The current technostress literature does not provide an understanding of design principles for such IS. We thus do not know how IS that could evaluate and affect key variables of the technostress process, can be designed. This line of investigation has the potential to explain issues relating to sensing, measuring and monitoring the presence of technostress and providing adaptation cues through the design of persuasive IS.

Fragmented investigation: The conceptual framing described in Sections 2 and 3 have been the predominant theoretical basis for studying technostress. However, as we see in Table 1, all aspects of it have not been investigated to the same extent. While techno-stressors and aspects of the technology environment have been examined, studies have not looked at primary or secondary appraisal, that is, the influencers of the relationship between environmental conditions and techno-stressors or between techno- stressors and coping responses. Studies on coping responses are also limited and do not explain how they affect outcomes. Further, most studies examine a direct relationship between techno-stressors and outcomes and its moderators, without considering the appraisal and coping processes.

Lack of inter-disciplinary theoretical enrichment: We find that the study of technostress in the IS literature, in conceptually framing technostress in the transaction model of stress, has referenced theoretical concepts from the psychological stress literature. While IS specific concepts have been developed for technostress creators and technology environment conditions, many of the key IS related variables and processes that constitute distinctive aspects of the phenomenon of technostress such as coping responses, appraisal and outcomes, are under-studied, and the related insights have not been incorporated into the understanding of psychological stress. This presents a substantive opportunity to develop the technostress literature in a way that furthers mutual and inter-disciplinary theoretical enrichment between the literature in IS and psychological stress.

Methods: Technostress being a process, it is not possible to measure 'technostress' as such. The presence of technostress has been assessed through the presence of the different variables and relationships that constitute it - techno-stressors, coping responses, and 
outcome or strain variables. We find (see Appendix C) that most empirical studies have reported on quantitative data collected through survey methods. Among the exceptions were: five studies that had experimental research designs, one study that was based on qualitative interviews, and one study that reported on both qualitative and quantitative. The experimental research designs simulated tasks from standard psychology tests rather than on organizational tasks. Two of them reported on physiological measures - presence of the salivary alpha amylase - as outcomes. In one of them (Galluch et al. 2015), results from the survey measure did not corroborate with those from the physiological measure. One paper was conceptual and did not report on any empirical data.

\section{FRAMING FUTURE RESEARCH- THE TECHNOSTRESS TRIFECTA}

Based on the literature analysis in Section 4 and the background presented in Sections 2 and 3, we present our framework for guiding future research in technostress in the form of a trifecta as shown in Figure 1. Its first aspect is techno-eustress, which explains how individuals appraise IS as challenging or thrilling, and experience consequent 'good' stress which motivates them to engage in coping behaviours that lead to positive outcomes. Its second aspect is techno-distress, which explains the processes by which individuals appraise IS as a threat, experience consequent 'bad' stress, and are faced largely with detrimental outcomes. Each of these two aspects is associated with a distinct process. The third aspect explains how IS can be designed, for respectively enhancing techno-eustress and mitigating techno-distress. 
Figure 1: The Technostress Trifecta

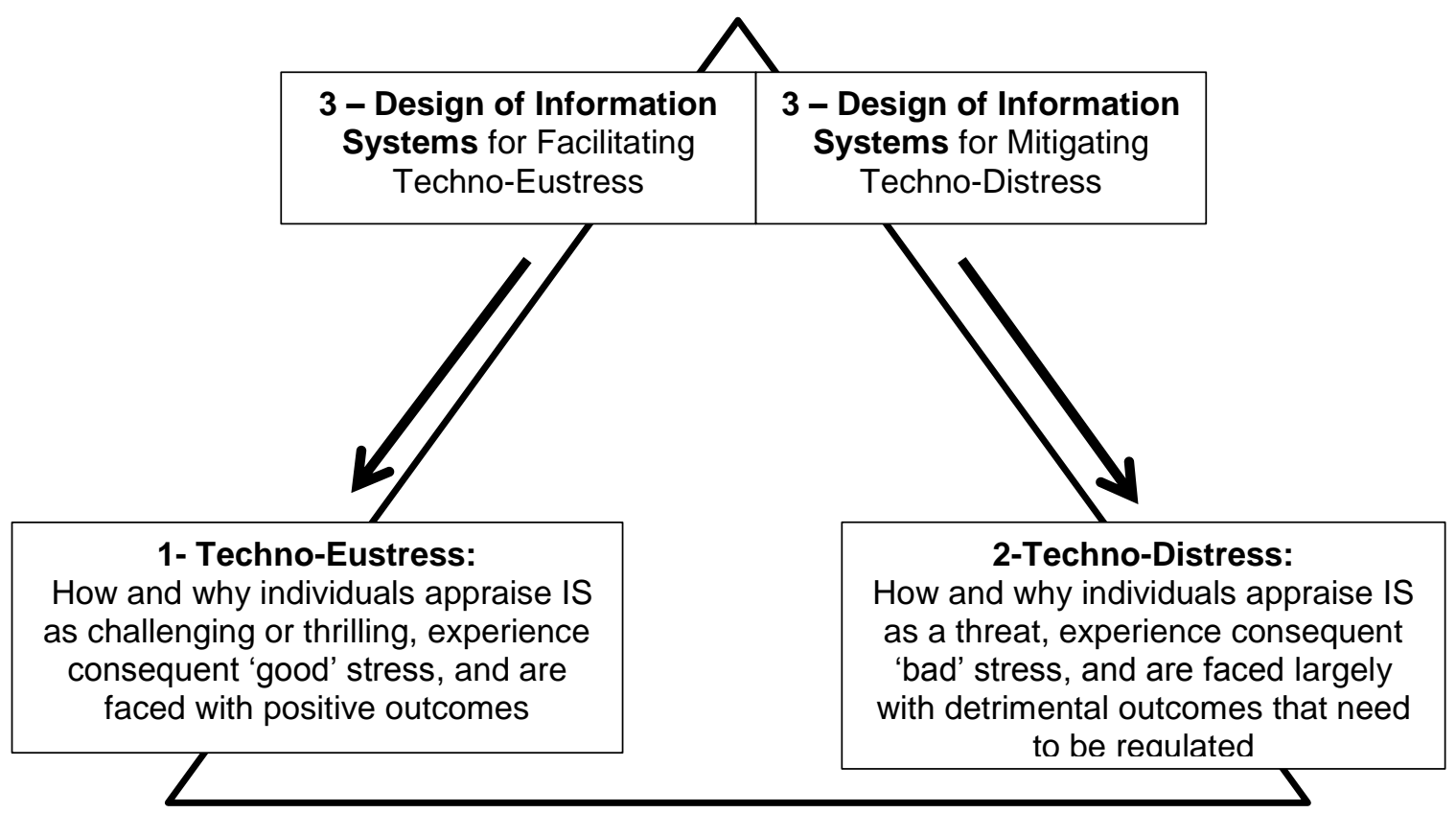

We next identify key research questions that future research should investigate for each aspect of the trifecta. We also suggest potential directions of enquiry for researchers to engage with these questions, based on IS and psychological stress literatures, and practice observations. These are discussed next and summarized in Table 2.

Table 2. Agenda for Research in Technostress

\begin{tabular}{|c|c|c|}
\hline Trifecta Aspect & Research Questions & $\begin{array}{l}\text { Potential Directions for Enquiry (based } \\
\text { on discussions in Sections 4.1, } 4.2 \text { and } \\
4.3 \text { ) }\end{array}$ \\
\hline \multicolumn{3}{|c|}{ Trifecta Aspect: Techno-Eustress } \\
\hline $\begin{array}{l}\text { Challenge Techno- } \\
\text { Stressors: } \\
\text { Perception of IS as } \\
\text { opportunity for } \\
\text { enhancing skills, } \\
\text { tasks, and work- life } \\
\text { activities }\end{array}$ & $\begin{array}{l}\text { What demands do individuals } \\
\text { experience from use of IS that they } \\
\text { find thrilling, enjoyable or } \\
\text { motivating? }\end{array}$ & $\begin{array}{l}\text { Demands that present opportunity for the } \\
\text { use of IS for: learning, enhancing skills, } \\
\text { accomplishing tasks more effectively, } \\
\text { enhancing performance, fulfilling career } \\
\text { ambitions }\end{array}$ \\
\hline $\begin{array}{l}\text { Primary Appraisal } \\
\text { for Challenge } \\
\text { Techno-Stressors: } \\
\text { Evaluation of IS as a } \\
\text { challenge and a } \\
\text { motivating factor }\end{array}$ & $\begin{array}{l}\text { What individual and organizational } \\
\text { factors increase the likelihood that } \\
\text { the characteristics of IS are } \\
\text { perceived as challenge techno- } \\
\text { stressors? } \\
\text { How do these factors strengthen } \\
\text { the relationship between } \\
\text { technology characteristics and } \\
\text { challenge techno-stressors? }\end{array}$ & $\begin{array}{l}\text { Individual: e.g. hardy personality, open to } \\
\text { experience, personal innovativeness and } \\
\text { initiative with IT } \\
\text { Organizational: e.g. culture of innovation } \\
\text { and high user involvement in IS, jobs have } \\
\text { levels of responsibility with time pressure }\end{array}$ \\
\hline $\begin{array}{l}\text { Challenge Coping } \\
\text { Responses: Actions } \\
\text { and affect to achieve }\end{array}$ & $\begin{array}{l}\text { What affect-related and action- } \\
\text { related coping responses are } \\
\text { activated to deal with challenge }\end{array}$ & $\begin{array}{l}\text { IS use related actions: e.g. } \\
\text { experimentation and exploration with IS }\end{array}$ \\
\hline
\end{tabular}




\begin{tabular}{|c|c|c|}
\hline $\begin{array}{l}\text { mastery over IS use } \\
\text { for work tasks }\end{array}$ & $\begin{array}{l}\text { techno-stressors that help } \\
\text { individuals achieve mastery over IS } \\
\text { use for work tasks? }\end{array}$ & $\begin{array}{l}\text { Task related actions: e.g. task } \\
\text { experimentation, productive multi-tasking, } \\
\text { flexible switching across devices and } \\
\text { work-home boundaries } \\
\frac{\text { Affect related: e.g. excitement and }}{\text { anticipation }}\end{array}$ \\
\hline $\begin{array}{l}\text { Secondary Appraisal } \\
\text { for Challenge } \\
\text { Coping Response: } \\
\text { Evaluation of coping } \\
\text { response to IS as a } \\
\text { challenge }\end{array}$ & $\begin{array}{l}\text { What factors increase the likelihood } \\
\text { of the individual activating } \\
\text { challenge coping responses in } \\
\text { response to challenge techno- } \\
\text { stressors? } \\
\text { How do these factors influence the } \\
\text { relationship between challenge } \\
\text { techno-stressors and challenge } \\
\text { coping responses? }\end{array}$ & $\begin{array}{l}\text { Individual factors: e.g. technology } \\
\text { competence, intrinsic motivation to use IS } \\
\text { Organizational factors: e.g. expectations } \\
\text { regarding client interaction } \\
\text { Role related factors: e.g. occupation } \\
\text { specific roles such as frontline service, } \\
\text { knowledge work }\end{array}$ \\
\hline $\begin{array}{l}\text { Positive Outcomes: } \\
\frac{\text { Positive and }}{\text { affirmative }} \\
\text { consequences relating } \\
\text { to IS use and work } \\
\text { tasks }\end{array}$ & $\begin{array}{l}\text { What are the positive outcomes } \\
\text { relating to task and use of IS? } \\
\text { How are various coping responses } \\
\text { related to different outcomes? }\end{array}$ & $\begin{array}{l}\text { Task related: e.g. improved efficiency, } \\
\text { productivity, innovation, performance, } \\
\text { achievement. } \\
\text { Use of IS related: e.g. heightened flow, } \\
\text { enjoyment and immersion while using IS. } \\
\text { Job related: work flexibility, work } \\
\text { engagement and work autonomy }\end{array}$ \\
\hline \multicolumn{3}{|c|}{ Trifecta Aspect:Techno-Distress } \\
\hline $\begin{array}{l}\text { Primary Appraisal } \\
\text { for Threat Techno- } \\
\text { Stressors: } \\
\text { Appraisal of IS as } \underline{a} \\
\text { threatening and a } \\
\underline{\text { disturbing factor }}\end{array}$ & $\begin{array}{l}\text { What factors increase the likelihood } \\
\text { that the characteristics of IS are } \\
\text { perceived as threat techno- } \\
\text { stressors? } \\
\text { How do these factors strengthen } \\
\text { the relationship between } \\
\text { technology characteristics and } \\
\text { threat techno-stressors? }\end{array}$ & $\begin{array}{l}\text { Individual: e.g. obsessive compulsive } \\
\text { personality, neurotic disposition, low } \\
\text { technology self-efficacy } \\
\text { Organizational: e.g. culture of } \\
\text { surveillance, expectations of work-related } \\
\text { availability outside work, low user control } \\
\text { over IS use }\end{array}$ \\
\hline $\begin{array}{l}\text { Threat Coping } \\
\text { Responses: } \\
\text { Actions and affect to } \\
\text { deal with the threat }\end{array}$ & $\begin{array}{l}\text { What negative and positive affect- } \\
\text { related, and action-related coping } \\
\text { responses are activated to deal } \\
\text { with threat techno-stressors that } \\
\text { help individuals deal with the } \\
\text { threat? }\end{array}$ & $\begin{array}{l}\text { IS use related: e.g. learning how to use } \\
\text { IS, accomplishing IS-mediated tasks, } \\
\text { seeking related training and assistance, } \\
\text { avoiding or stopping IS use } \\
\text { Task related: e.g. changing IS-mediated } \\
\text { tasks to fit with the technology, temporarily } \\
\text { stepping away from the IS-mediated task } \\
\text { Cognition related: e.g. rationalizing and } \\
\text { reinterpreting the threat in a positive light } \\
\text { Social and interpersonal related: e.g. } \\
\text { venting, co-rumination } \\
\text { fffect related: e.g. anger, annoyance, } \\
\text { frustration, hope }\end{array}$ \\
\hline $\begin{array}{l}\text { Secondary Appraisal } \\
\text { for Threat Coping } \\
\text { Responses: } \\
\text { Evaluation of coping } \\
\text { response to IS as a } \\
\text { threat }\end{array}$ & $\begin{array}{l}\text { What factors increase the likelihood } \\
\text { of the individual activating particular } \\
\text { threat coping responses when they } \\
\text { face threat techno-stressors? } \\
\text { How do these factors influence the }\end{array}$ & $\begin{array}{l}\text { Individual: e.g. resilience, optimism } \\
\text { Technology support: e.g. troubleshooting/ } \\
\text { help desks, IS awareness programs } \\
\text { Social support: e.g. peer socialization }\end{array}$ \\
\hline
\end{tabular}




\begin{tabular}{|c|c|c|}
\hline & $\begin{array}{l}\text { relationship between threat techno- } \\
\text { stressors and threat coping } \\
\text { responses? }\end{array}$ & $\begin{array}{l}\text { around IS } \\
\text { Work practices support: e.g. flexible } \\
\text { working schedules }\end{array}$ \\
\hline $\begin{array}{l}\text { Outcomes } \\
\begin{array}{l}\text { Negative behavioral, } \\
\text { psychological and } \\
\text { physiological } \\
\text { consequences }\end{array} \\
\underline{\text { Positive }} \\
\text { consequences relating } \\
\text { to IS use and work } \\
\text { tasks }\end{array}$ & $\begin{array}{l}\text { How do different coping responses } \\
\text { lead to different coping outcomes? } \\
\text { Under what conditions do coping } \\
\text { responses lead to positive and } \\
\text { negative outcomes? } \\
\text { How do these conditions influence } \\
\text { the relationship between coping } \\
\text { responses and outcomes? }\end{array}$ & $\begin{array}{l}\text { Regulation of: } \\
\text { Negative behavioral outcomes: e.g. lack of } \\
\text { use or suboptimal use of IS } \\
\text { Negative psychological outcomes: e.g. job } \\
\text { satisfaction, dissatisfaction with IS, job } \\
\text { commitment, burnout } \\
\text { Negative physiological outcomes: e.g. } \\
\text { physical problems, biochemical or } \\
\text { neuroendocrine indicators } \\
\text { Positive outcomes: } \\
\text { Task related: e.g. problem solving, } \\
\text { Use of IS related: e.g. learning to use IS. }\end{array}$ \\
\hline \multicolumn{3}{|c|}{ Trifecta Aspect: Designing IS to tackle Technostress } \\
\hline $\begin{array}{l}\text { Leverage challenge } \\
\text { techno-stressors and } \\
\text { reduce threat techno- } \\
\text { stressors }\end{array}$ & $\begin{array}{l}\text { What IS design features motivate } \\
\text { and empower users to leverage } \\
\text { challenge techno-stressors? } \\
\text { What IS design features provide } \\
\text { simplicity and clarity to help } \\
\text { individuals reduce threat techno- } \\
\text { stressors? }\end{array}$ & $\begin{array}{l}\text { Features that strengthen thrill, enjoyment, } \\
\text { competitiveness, e.g. gamification to } \\
\text { enhance enjoyment, allowing users to } \\
\text { install, control and modify applications } \\
\text { Features that make it simple to use IS e.g. } \\
\text { e.g. easy navigation, consistent } \\
\text { functionality, opt-out options, clear } \\
\text { information, information prioritization }\end{array}$ \\
\hline $\begin{array}{l}\text { Design IS to help the } \\
\text { individual in executing } \\
\text { challenge and threat } \\
\text { coping behaviors }\end{array}$ & $\begin{array}{l}\text { What IS design features motivate } \\
\text { the individual to engage in } \\
\text { challenge coping behaviors? } \\
\text { What IS design features assist the } \\
\text { individual in threat coping } \\
\text { behaviors? }\end{array}$ & $\begin{array}{l}\text { Features that support emergent use, e.g. } \\
\text { flexibility in features and interfaces to } \\
\text { support workarounds, experimentation } \\
\text { and model building } \\
\text { Features that provide calming and } \\
\text { distraction, e.g. easily understood help } \\
\text { menus and use guidance, positive } \\
\text { feedback regarding IS use, options to take } \\
\text { a break from IS use } \\
\frac{\text { Features that provide support for social }}{\text { processes, e.g. informal chats and }} \\
\text { postings }\end{array}$ \\
\hline $\begin{array}{l}\text { Design IS to enhance } \\
\text { positive outcomes and } \\
\text { diminish negative } \\
\text { outcomes }\end{array}$ & $\begin{array}{l}\text { What IS design features provide } \\
\text { psychological reinforcement for } \\
\text { improved performance, to } \\
\text { accentuate positive coping } \\
\text { outcomes? } \\
\text { What IS design features provide } \\
\text { persuasion to attenuate negative } \\
\text { coping outcomes? }\end{array}$ & $\begin{array}{l}\text { Features that: } \\
\text { Identify behavioral and physiological } \\
\text { parameters that indicate positive and } \\
\text { negative outcomes } \\
\text { Measure and track positive and negative } \\
\text { outcomes } \\
\text { Provide helpful and relevant feedback in } \\
\text { an unobtrusive and non-interfering } \\
\text { manner that help to attain goals regarding } \\
\text { outcomes } \\
\text { Consider the distinctive particulars of the } \\
\text { task, application, and occupation/role }\end{array}$ \\
\hline
\end{tabular}


Figure 2 presents our conceptualization of the Techno-Eustress and Techno-Distress aspects of the trifecta. It draws from the theoretical framing of the Transactional approach to studying technostress. We conceptualize Techno-Eustress and Techno-Distress as two distinct transactional phenomena. Each phenomenon unfolds differently, but within the overall framing of the Transactional approach. That is, each has conceptually similar but qualitatively different concepts and relationships among them. In the next two subsections, we describe each in greater detail.

\section{Figure 2: Techno-Eustress and Techno-Distress}

Note: Concepts marked with an asterix have been covered to a larger extent in the literature. Although we do not suggest that they have been completely addressed, we focus on those aspects which the literature does not address.

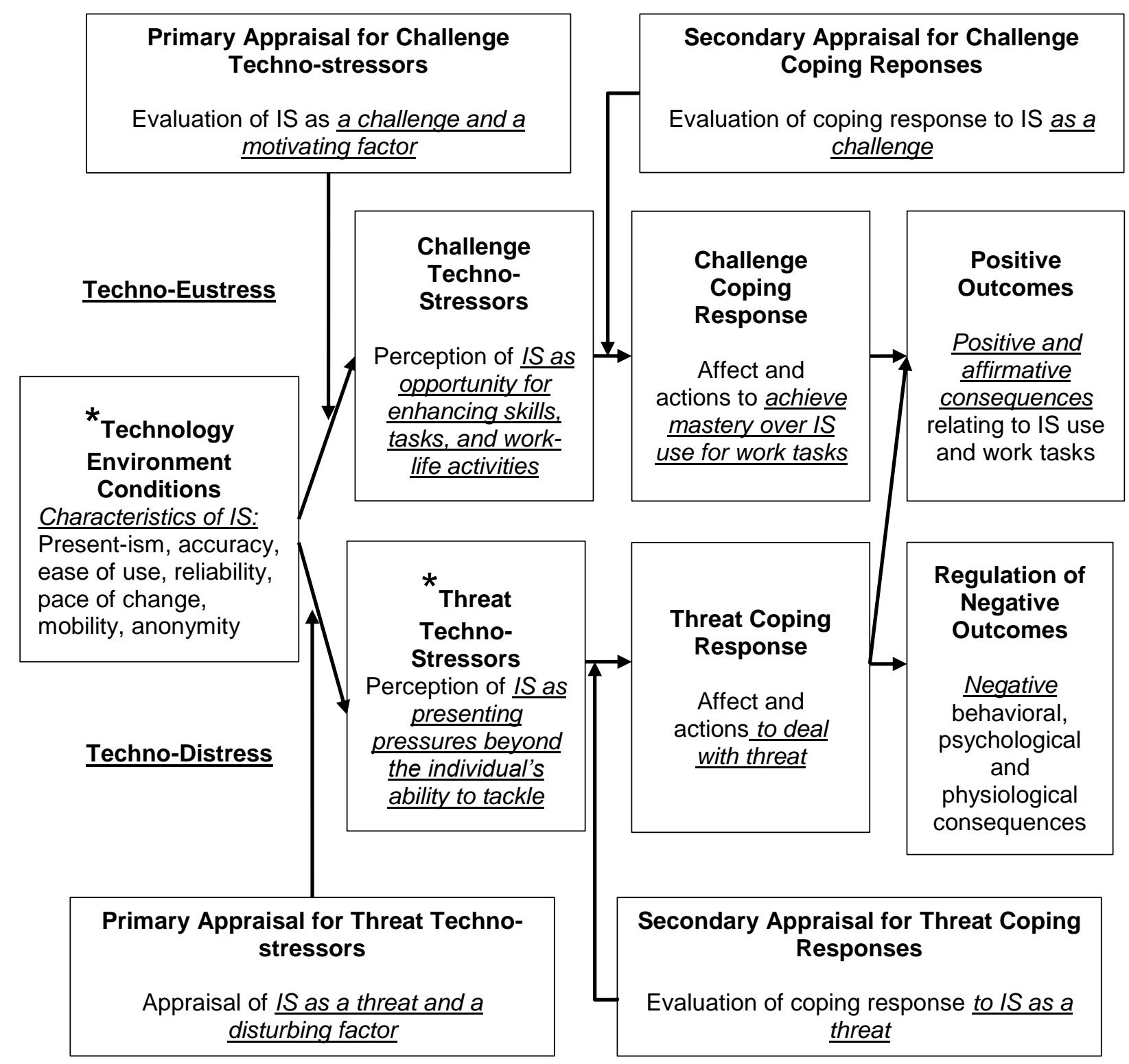




\subsection{Techno-Eustress}

Techno-Eustress is the phenomenon that embodies the positive stress that individuals face in their use of IS. As shown in the top half of Figure 2, individuals appraise the characteristics of IS as challenges that they are motivated to tackle because they expect that doing so is within their wherewithal and would lead to betterment, activate coping behaviors to master the challenges in a positive way, and achieve largely affirmative and positive outcomes. In doing all of this, the individual experiences the process of 'eustress' or 'good' technostress.

Challenge Techno-stressors: Challenge stressors are perceived as opportunities or options for change, learn, achieve, and reward (Cooper et al 2001; Fay et al 1998). The individual experiences 'challenge' techno-stressors when the characteristics of IS are perceived to present the opportunity and option for enhancing and improvement the individual's skills, tasks, and work life. Recent studies show for instance that individuals can push themselves to learn how to use apps on smartphones and tablets to enhance their flexibility across different tasks, contexts and the work-home boundary (e.g. Diaz et al. 2012; Leung 2011; Ohly and Latour 2014). It is important to understand what these challenge stressors are in order to evaluate the ways in which the individual can feel challenged. We thus ask the question: How can challenge techno-stressors be conceptualized? What demands do individuals experience from the characteristics of IS that they find thrilling, enjoyable or motivating?

Primary Appraisal for Challenge Stressors: Particular individual and organizational characteristics increase the likelihood that the characteristics of IS are perceived as challenge stressors. These factors strengthen the relationship between technology characteristics and the challenge perceived by the individual due to them. In terms of individual-specific characteristics, certain personality characteristics included in the 'big five' (Goldberg 1990) may be pertinent. For instance, individuals with a hardy personality, characterized by alertness, ambition and competitiveness, are intrinsically motivated to achieve and perform at high levels. They interpret environmental conditions as challenges that can be leveraged for positive work outcomes (Kobasa 1979; Janis 1977). Such individuals may perceive IS characteristics such as presentism and reliability as enablers for accessing and processing information when they need it, and for increasing their ability to be flexible and productive (Boswell and Olson-Buchanan 2007; Ohly et al. 2015). Or, individuals who are open to experience, actively try out and seek new situations, think creatively and unconventionally or show high levels of initiative and innovativeness with IS 
(Agarwal and Pradad 1998). They may perceive IS functionality as an opportunity for innovative use. They would evaluate IS characteristics such as pace of change, sophistication, and flexibility as opportunities to creatively use and experiment with new IS functionalities and features; they would thus be challenged by them to enhance their work.

Particular job characteristics or aspects of organization culture can aid in the primary appraisal for challenge techno-stressors. Job characteristics that combine high levels of job responsibility with time pressure may propel individuals to turn toward IS to increase their efficiency and performance (Cavanaugh et al. 2000). A culture of innovation makes it acceptable to take risks (Amabile et al. 1996). In organizations having such a culture, flexibility of IS may be seen as an opportunity for the creative use of technology for work tasks, and the pace of change of IS, as a challenge for using new technologies for innovative work processes. Additionally, a culture of involvement enables influential roles for users in IS planning, development, and implementation (Doll and Torkzadeh 1989). In such a culture, users are familiar with the system, understand how to use its features, and make better assessments about task-technology fit (Beaudry and Pinsonneault 2005). Armed with this knowledge, they may perceive technology characteristics such as flexibility, as opportunities that challenge them to improve their tasks, by using IS in different ways.

Understanding what these personal and organizational factors are, is necessary to explain what helps in the appraisal of challenge stressors, so that we ask: What individual and organizational factors increase the likelihood that the characteristics of IS are perceived as challenge stressors? How do these factors strengthen the relationship between technology characteristics and challenge techno-stressors?

Challenge Coping Responses: A key psychological concept critical to dealing with challenges is that of mastery, which denotes the successful meeting and dealing with difficulties (Murphy 1962). Mastery focuses the individual's actions toward leveraging the opportunities associated with the challenge, for achievement and fulfilment (Lazarus and Folkman 1984; Lazarus 1966). Challenge coping represents such actions and is directed toward achieving competence and mastery. They are activated when the individual experiences challenge techno-stressors. They can be related to the individual's use of IS and the task.

Coping responses can be affect-based or action-based (Folkman et al. 1896; Lazarus 1966; Lazarus and Folkman 1984). They can exist simultaneously (Fay et al. 1998). For the former, IS use related coping emotions that spur the individual to act in positive ways could include excitement and anticipation (Beaudry and Pinsonneault 2010). With respect to the 
latter, IS use-related coping behaviors can focus on experimenting with different types of use such as - exploring and trying new features (Barki et al. 2007; Jasperson et al. 2005; Beaudry and Pinsonneault 2005), using more features (Sun 2012), and uncovering new uses for existing features (Jasperson et al. 2005; Singletary et al. 2002). They would entail proactively 'stretching' and learning to use new IS and seeking support for doing so (Beaudry and Pinsonneault 2010; DeSanctis and Poole 1994; Orlikowski and Gash 1994). Task related coping behaviors are focused on innovations and adaptations in task and work practices using IS (Beaudry and Pinsonneault 2010; Majchrzak and Cotton 1988). Task innovation could include, for instance, developing new solutions for customers using a customer relationship management system (Tarafdar et al. 2015). Work practice innovation could include discretionary and mindful smartphone use for work-related tasks at home to achieve flexibility (Fenner and Renn 2010), productive multi-tasking during meetings when the individual is not directly contributing or speaking, by working simultaneously on other ISmediated tasks (Ohly and Latour 2014), use of IS to engage in back and forth between different types of communications and interactions during the course of the workday to accomplish various tasks (Wajcman and Rose 2011). Recent research supports such scenarios and suggests that boundaries across different work tasks can be blurred in a constructive and helpful way (e.g. Leung 2011) through the use of IS. We therefore ask: What IS use related and task related coping responses are activated to deal with challenge techno-stressors that helps individuals achieve mastery over IS use for work tasks?

Secondary appraisal for challenge coping responses: Secondary appraisal for challenge coping increases the likelihood that individuals evaluate and engage in various challenge coping responses. Factors that could influence secondary appraisal are the individual's technology skills, organizational norms regarding particular tasks, and the individual's organizational role.

In terms of technology skills, individuals with high technology competence, that is, those who can use IS productively and with ease (Tarafdar et al. 2015), are likely to be motivated and stimulated by and thrive on, creative and exploratory uses of IS. Similarly those with a high intrinsic motivation to use IS (Ryan and Deci 2000) would proactively engage in IS use for the fun and challenge it provides. Recent findings show that intrinsic motivation may be a positive factor in people using smartphones for changing their work practices (Ohly and Latour 2014). Organizational expectations and norms regarding how particular tasks should be regarded are likely to be important to secondary appraisal because they influence how individuals use IS to accomplish their tasks (DeSanctis and Poole 1984; 
Orlikowski 1992). In organizations where prompt and constant interaction with high-value and demanding clients is expected, employees may attune their work practices toward maximum availability and would accordingly use IS to ensure that they can be reached by clients (Mazmanian et al. 2013). These sorts of organizational expectations influence the likelihood that the individual reacts to the challenge stressors by engaging in IS use and task related coping behaviors that enable them to achieve mastery over their work. In terms of the individual's role, frontline roles such as call center management and customer service require support to the customer. Individuals in such roles are likely to engage in coping behaviors that enable them to answer questions from and engage in communication with customers (Wajcman and Rose 2011). As another example, knowledge workers need to keep abreast of latest developments in their fields. Individuals in such roles may respond to challenge stressors by using IS to receive information alerts from important journals and databases.

We thus ask the following questions: What individual, organizational and role related factors increase the likelihood of the individual activating challenge coping responses when they face challenge techno-stressors? How do these factors influence the relationship between challenge techno-stressors and challenge coping responses?

Positive outcomes: Outcomes beneficial to the individual are expected to occur in the techno-eustress process. Such outcomes embody affirmative and positively reinforcing impacts for the individual. They could include, for example, improved performance, increased efficiency and enhanced innovation at work tasks through the use of IS. Recent studies show that when employees in frontline roles use IS under positive or motivating pressures, the result can be increased efficiency (e.g., reducing time and effort, work faster, make fewer errors) and effectiveness (e.g., improving the quality of services, upselling), which results in improved performance (Wajcman and Rose 2011). When the individual engages in challenge coping behaviors such as experimentation and problem solving with IS, he or she is able to better leverage IS for increased task efficiency, and experience a general overall positive feeling while using IS. Challenge coping outcomes thus may include heightened flow or enjoyment and immersion in the use of, and an overall positive feeling towards, IS. Positive outcomes relating to the individual's overall job could include enhanced work flexibility, greater overall work engagement and an improved sense of work autonomy (ter Hoeven and van Zoonen, 2015).Understanding what these positive outcomes are, is essential to assessing the benefits of techno-eustress, so that we ask: What are the positive outcomes relating to task and use of IS? How are various coping responses related to different outcomes? 


\subsection{Techno-Distress}

In contrast to Techno-Eustress, Techno-Distress is the phenomenon that embodies the negative stress that individuals face in their use of IS. As shown in the bottom half of Figure 2, individuals appraise the characteristics of IS as threatening and presenting pressures beyond their ability to tackle. Moreover he or she perceives significant negative consequences to not tackling them (Ragu-Nathan et al 2008). Such perceptions may activate coping responses, the outcomes of which constitute the containing and keeping in check of factors that are detrimental (Pearlin et al. 1981). As we see in Table 1 and Figure 2, the literature has investigated the following aspects of Techno-Distress: Threat Techno-stressors and Negative Outcomes. The other aspects have however not been adequately attended to and present greater opportunity for further research.

Primary Appraisal for Threat Techno- Stressors: While threat techno - stressors have been discussed in the literature (e.g. Ayyagari et al. 2011; Day et al. 2012; Ragu-Nathan et al. 2008), why and how individuals appraise threat techno- stressors has not been explained. Particular individual and organizational characteristics increase the likelihood that the characteristics of IS are perceived as threat techno- stressors. For instance, individuals with obsessive compulsive personalities or neurotic dispositions tend to interpret environmental conditions as threat stressors (Bolger and Zuckerman 1995; Chang 1998) because they are likely to be anxious, paranoid, and prone to negative reactions to situations. They have a tendency to perceive difficult situations as threatening (Lauriola and Levin 2001; Spector et al. 2000). Such individuals may perceive the reliability and presentism of IS as requirements for being available for work round the clock, feel insecure about missing out on important matters if they are not, and feel disturbed by the blurring of boundaries between work and home, thus strengthening the relationship between IS characteristics and threat techno-stressors. Additionally, individuals with low self-efficacy are likely to appraise greater job demands as threats (Schaubroeck and Merritt 1997). Low technology self-efficacy (Compeau and Higgins 1995) therefore could reduce the individual's confidence in dealing with IS characteristics such as flexibility and pace of change and increase the perception of threat associated with them.

In terms of characteristics of the organization, a surveillance prone culture implies IS enabled monitoring of employees, which can generate in them, fears of job insecurity, loss of privacy, and infringement of personal space (Fairweather 1999; Zuboff 1988, 2015). This is especially relevant for example, for organizations that monitor and record keystroke information, call center type telephone conservations with clients for assessing task speed and 
accuracy, and e-mail and Internet use (Miller and Weckert 2000; Stanton and Weis 2000). In such organizations, IS characteristics of reliability and anonymity can be perceived as enablers of even greater surveillance, further enhancing these fears (Coovert and Thompson 2005; Fairweather 1999). Organizational expectations of availability for work, outside of work hours may force individuals to respond immediately to communication such as email, texts or social networking applications (Barber and Santuzzi 2015). Individuals in such organizations may perceive reliability and presentism as threatening conditions that compel them to stay available for work all the time. At the same time, the extent to which individuals are in control over their own IS use enables them to choose when and how they use IS, such that they feel less threatened and overwhelmed by the IS characteristics.

We thus frame the following research questions: What individual and organizational factors increase the likelihood that the characteristics of IS are perceived as threat technostressors? How do these factors strengthen the relationship between technology characteristics and threat techno-stressors?

Threat Coping Responses: A second under-researched aspect is that of threat coping responses. These constitute actions or emotions to overcome or deal with the threat or hindrance the individual perceives from the threat techno-stressors.

From the general literature on coping, it is possible to suggest that coping actions could include four kinds of behaviors - altering the task in the context of which the threat techno-stressor is experienced, changing the way in which the stress inducing IS is used, changing one's cognition about the threat techno-stressor, and engaging in social behaviors. Coping behaviors for altering tasks could include adjusting or changing the work procedures such that they fit they better fit with the technology (Beaudry and Pinsonneault 2005; Majchrzak et al. 2000) and distancing or stepping away from the technology mediated task for a while (Beaudry and Pinsonneault 2010; Galluch et al 2015) and engaging in a different activity before returning. Coping behaviors relating to IS use could be learning how to use IS to the extent required for accomplishing tasks, seeking related training and assistance, or avoiding or stopping use (Bala and Venkatesh 2015; Beaudry and Pinsonneault 2005). The intent of IS use in this way would not be for innovation or improvement, but for merely getting the task done. Changing the outlook toward a threat techno-stressor would involve reinterpreting and viewing it in a positive light and rationalizing or minimizing its supposed significance such that it appears less threatening. Such coping could include attitudes expressed by remarks such as 'The system is not really as bad as it is made out to be' (Beaudry and Pinsonneault 2005). Social and interpersonal behaviors can include venting, 
seeking social support and co-rumination (Beaudry and Pinsonneault 2010; Helgeson 2011; Skinner and Zimmer-Gembeck 2011).

Traditionally, studies have considered negative emotions such as anger, annoyance, anxiety and frustration as coping responses, (see, for example, Lazarus 1966). Negative emotions have been examined in the context of potentially upsetting or discrepant IS situations such as implementation of new IS (Beaudry and Pinsonneault 2010; Stein et al 2015). However, emerging ideas in stress (Folkman 2011), drawing from positive psychology (Seligman and Csikszentmihalyi 2000), are beginning to examine how positive affect can sustain individuals when they experience stressors. Techno-stressors, especially technoinsecurity and techno-uncertainty, can disturb the individual's sense of equilibrium because they disrupt valued job related aspects such as continuity and stability. Going forward, it is important to examine how positive emotions such as hope could embody positive coping affect in dealing with these sorts of threat techno-stressors.

We thus ask the following research questions: What coping responses (e.g. IS use related, task related, negative and positive affect related) are activated to deal with threat techno-stressors that help individuals overcome the threat?

Secondary Appraisal for Threat Coping: Secondary appraisal for threat coping increases the likelihood that individuals engage in threat coping behaviors in response to threat techno-stressors. While many negative outcomes have been examined, there is no understanding of how coping behaviors that influence those outcomes are activated.

Individual factors influencing the selection of threat coping responses could include personality related attributes such as optimism and resilience. These traits, in the general sense, are instrumental to whether individuals demonstrate positive or negative affect as a coping response. Specific to IS use, there is scope for developing and clarifying concepts such as IT related resilience or mindfulness, and examining their influence on the extent to which individuals undertake specific coping repsonses.

Organizational factors that could influence secondary appraisal for threat technostressors should provide a supporting organizational environment (Fenlason and Beehr 1994; Lim 1996; O'Driscoll et al. 2010) in which users can engage constructively with IS related tasks even as they face threat techno-stressors. They include social support, technology support and work process support. Social support from co-workers and friends includes good personal relationships through which they can empathize, understand and support each other in the context of IS use (Salanova et al. 2013; Zorn 2002). Such socialization encourages peer learning and helps individuals to share their experiences of IS use and make positive 
attributions to it. Technology support includes organizational mechanisms that help employees understand IS and how they can be used. They could include help desk type mechanisms for resolving technical faults (Beas and Salanova 2006; Ragu-Nathan et al. 2008) as well as programs that make individuals aware of issues surrounding IS use such as work life balance and help them become aware of options such as filtering email and switching off devices, as responses to threat stressors (Salanova et al. 2014). Work process support includes tractability in the individual's work organization such as for instance, provision of flexible schedules through teleworking (Leung 2011; Salanova et al. 2013; Salanova et al. 2014). Such support helps individuals choose their own ways of doing IS mediated tasks in response to threat techno-stressors.

Understanding these sorts of support would shed light on conditions for the individual to improve their outlook, in response to threat techno-stressors. We ask the following questions: What individual and organizational factors increase the likelihood of the individual activating particular threat coping responses in response to threat technostressors? How do these factors influence the relationship between threat techno-stressors and threat coping responses?

Outcomes: Studies in technostress have considered many negative outcomes. However, the focus of coping responses is to regulate and manage the negative outcomes. Thus, the extent to which outcomes are negative depends on the extent to which coping responses are successful (Folkman et al 1986; Lazarus 1966). For example the coping action of changing the way in which an IS is used can decrease the extent of a negative outcome such as dissatisfaction with the IS to a larger degree, if the individual is skilled at using the specific IS. Similarly, the efficacy of a coping emotion such as frustration in regulating a negative outcome such as discontinuation of IS use, might depend on the presence of others who are experiencing similar frustrations and can mutually share. Therefore, whether or not a coping response leads to satisfactory outcomes, depends on the context in which it takes places. Indeed, efficacious coping actions could lead to positive outcomes even when threat techno-stressors are perceived. Recent studies show that users can experience a mix of positive and negative emotions that spurs them to engage to a greater extent with IS even in an IS related disruptive situation (Stein et al. 2015). Or, individuals could adopt coping actions such as problem solving and learning, which could actually increase their effectiveness of IS use (Beaudry and Pinsonneault 2005; Ortiz de Guinea 2016). Thus, it is possible to suggest that coping responses could lead to positive outcomes even in a technodistress process. We ask the following questions: How do different coping responses lead to 
different coping outcomes? Under what conditions do coping responses lead to positive and negative outcomes? How do these conditions influence the relationship between coping responses and outcomes?

\subsection{Designing IS to tackle Technostress}

The third component of the technostress trifecta explains how IS can help mitigate technodistress and enhance techno-eustress. We do this by identifying design principles for IS that can effect interventions to tackle techno-eustress and techno-distress. Research suggests that when individual face disruptions and stress due to IS, interventions to facilitate adjustments can be applied at three levels - primary, secondary and tertiary. Primary intervention involves efforts to manage the level of the stress creating conditions. Secondary interventions focus on influencing the individual's coping response to such conditions. Tertiary interventions influence the outcomes that the individual experiences (Nelson and Kletke 1995, Cooper et al 2001). We draw from this framing to suggest that correspondingly, IS designed to effect interventions to help tackle techno-distress and techno-eustress can be used by individuals at three possible points respectively: (1) when they face challenge or threat stress creating conditions or techno-stressors (primary intervention); (2) when they execute challenge or threat coping responses (secondary intervention); and (3) when they experience positive or negative outcomes (tertiary intervention). The research opportunity associated with the third trifecta component is thus to investigate design features of IS that can be used at each of these points as we show in Figure 3.

\section{Designing IS to leverage challenge techno-stressors and reduce threat techno-}

stressors: It is essential to understand the design principles for IS that help individuals deal with challenge and threat techno-stressors, so that appropriate interventions can be effected at the very start of the techno-distress and techno-eustress process. Design features that stimulate and empower users to enhance their skills and performance using IS would help individuals leverage challenge techno-stressors by strengthening their perceptions of enjoyment, motivation and thrill. From the gaming literature we know that features that motivate users include IS that are fun and interesting, and encourage progress by presenting information about the individual's performance (Gerling et al. 2011). Such features can include tips, examples and suggestions about the possibilities of various types of use of the IS that can pique the individual's interest. Additionally, design features that allow users to install, control and modify features empower them to use IS to leverage the challenge stressors. 
Features that might help mitigate the perception of threat stressors could include a simple design interface that is easy to navigate so as to minimize techno-complexity relating to IS use, consistent application performance and functionality that would reduce technouncertainty, information prioritization features that would decrease techno-overload, and information on data collected that would reduce techno-insecurity. For example, if a user feels threatened due to loss of privacy, informing employees of what data is collected and providing a design feature to opt out can reduce that threat. Overall, design features that provide simplicity and clear/adequate information can reduce the extent of threat stressors (Johnson and Wiles 2003).

Thus we ask: What IS design features stimulate and empower users to leverage challenge techno-stressors? What IS design features provide simplicity and clarity to help individuals reduce threat techno-stressors?

Designing IS to aid in challenge and threat coping responses: Once the individual has appraised a threat or challenge techno-stressor, the next opportunity to intervene is by providing IS that assist with the individual's respective coping response. Challenge coping behaviors include task and IS use innovation using IS. Such innovation involves emergent interactions between task, technology and user, which are not scripted in advance, but arise through discussion, experimentation, adaptations, model building and workarounds, individually or in groups, as users figure out how to use the IS effectively and efficiently. It involves complex work processes that depend on the discretion of the user (Stein et al. 2015) and are enacted through multiple devices and sources of data, as users interact with task and technology to engage in innovation for both task and IS use (Alter 2008). Thus, systems which are designed to support emergence, flow and engagement may help execute challenge coping behaviors effectively (Alter 2010; Campbell and Pisterman 1996). Such systems could, for example, support the individual in workarounds, creative changes, experimentation and model building, by providing flexibility in features and interfaces.

Threat coping behaviors include individuals adjusting their task and use of IS, under feelings of distress and discomfort. The focus is on learning how to use the IS effectively and applying it to their work, often only to satisfy the minimum requirements of use (Stein et al. 2015). Helpful interventions can be those that calm and/or distract the individual (Weiser and Brown 1997). Calming interventions are IS features that provide easily understood help menus and use guidance to ease the individual's anxiety. Another calming mechanism could be to provide system generated feedback that reassures the individual about their outcomes regarding task adaptation or system use. For example, in an ERP system, this could be by 
providing a message through the system that communicates to the user that they successfully accomplished a given task (e.g. invoicing) by completing a specific IS use action (e.g. data entry on multiple screens into multiple tables) (Yim and Graham 2007). Regarding distraction interventions, any features that nudge users at the point of use, to take a break, switch off, step away, breathe deeply or do something different, help to make their threat coping responses more effective. A third intervention could be in the form of group or social support. Recent research (e.g. Pakenham 2011) shows that social processes such as collective sense-making of threatening or disturbing situations can be an effective means of coping. IS having features that can support such processes, such as applications having informal chat functions and postings could aid in threat coping responses.

Thus we ask: What IS design features support emergent use to assist in challenge coping behaviors? What IS design features provide calming, distraction and support for social processes to assist in threat coping responses?

\section{Designing IS to enhance positive outcomes and diminish negative outcomes:}

Finally, individuals can also use IS at the end of the techno-eustress and techno-distress processes, at the point where they experience positive and negative outcomes. Challenge outcomes are positive and desirable, such as improved performance, enhanced innovation and greater mastery. The goal of the IS should be to ensure that they continue. Design features that make individuals aware of these positive outcomes and reinforce their benefits can help do that. Positive outcomes can be directed towards task mastery, innovation and improved performance. It may be possible to translate such outcomes into parameters that the system can measure and communicate to the individual. An example of this could be of a call center application that keeps track of calls handled and generates congratulatory messages to users when calls are handled with increasing effectiveness and efficiency over time. Such messages could let individuals know, if they so choose, that their performance has improved, thus reinforcing their mastery.

In the case of negative outcomes, persuasive systems can measure negative outcomes, provide diagnostics, and suggest persuasion cues (Fogg 2003). Negative outcomes regarding users' emotions could be measured through for instance, eye-tracking devices, wearables, and instruments that track physiological parameters such as saliva etc. Such measurements can be processed by the system, and if the threshold exceeds a certain level specific to the individual, appropriate feedback can be given to him or her if he or she so chooses. For example, if a user is multitasking on several different application screens and is experiencing the threat stressor of techno-overload, then the resulting negative outcome could be an 
increased heartbeat or eye movement. This can be sensed by the persuasive system and the user presented with a screen message which suggests to them to reduce the number of applications or to take a break. Such IS could gather information about the individual's current state, process it by comparing against his or her target conditions, and feed it back to provide assistance on the task at hand (Derrick et al. 2011; Oinas-Kukkonen and Harjumaa 2009). They could also provide a history of outcomes that individuals can understand the situations under which they become distressed. Such a framing provides the opportunity for detecting a negative or distressful outcome, selecting an adjustment or intervention, implementation of the intervention and revisiting the outcome. These sorts of persuasive IS can be applied in the context of different techno-distress situations, such as multi-tasking on smartphones, and IS generated interruptions through email and other communication applications. It is important to keep in mind however that such persuasion itself should not happen in an obtrusive, undesired, and consequently stressful manner (Dennison et al. 2013; Kuonanoja et al. 2015).

Thus we ask the following questions: What IS design features provide psychological reinforcement for improved performance, innovation and mastery to accentuate positive coping outcomes? What IS design features provide persuasion to attenuate negative coping outcomes?

\section{DISCUSSION}

In this paper we take a big-picture and unified view of technostress to identify areas where future research can most fruitfully direct its attention. Our exposition of key areas where future studies can be directed brings the conceptual domains of IS design, use and management together with organizational behavior and psychological stress, suggesting that the study of technostress should draw from the richness contained in all of them. We challenge three key ideas imbued in the existing literature - that technostress is primarily a phenomenon that has negative and detrimental consequences, that the role of IS in the technostress process is limited solely to that of a stress creator, and that research in technostress primarily draw from the reference disciplines of psychological stress. The research agenda put forward in this paper advocates that future scholarly enquiry of technostress should reveal how beneficial outcomes can come from technostress, how appropriately designed IS can alleviate the negative and accentuate the positive aspects of 
technostress, and how research on technostress can inform the literatures of psychological stress and other disciplines that study workplace stress.

Inter - disciplinary Framing: Considered from the disciplinary perspective, the phenomenon of technostress is distinctive. On the one hand, it is hewn from the fundamental phenomenon of stress, and on the other, it cannot exist without, is unique to, and is driven by, the design, implementation and use of IS. Research on technostress thus poses an interesting challenge. One, it needs to consider the stress phenomenon. Two, it needs to uncover insights deeply embedded in the design, implementation and use of IS that relate to psychological stress, so as to develop an indigenous, IS-focused understanding of this phenomenon.

In our framing of technostress we address this challenge thus. First, we note that the phenomenon of stress has certain non-specific aspects (Selye 1956, 1974), which exist across all stress situations. Lazarus (1966) emphasizes the enduring and fundamental importance of three key non-specific aspects in psychological stress - the stimulus conditions that demand the change, how the demand is perceived and appraised, and the intervening coping related processes that determine when and in what form the outcomes will occur. Our conceptual framing of the Techno-eustress and Techno-distress processes recognizes this. Second, and equally importantly, within this general rubric, there are specific aspects that constitute contextual complexities and particularities (Lazarus 1966, Cooper and Dewe 2004). To address this, we pose research questions that focus on the design, implementation and use of IS as constitutive of its specific and substantive aspects. We thus highlight the need to address concepts and relationships distinctive to IS such as, for example, challenge techno-stressors, IS use related coping responses, IS use related positive and negative outcomes, and IS design interventions to develop an IS centered understanding of these aspects.

So far, research in technostress (based in the IS discipline) has primarily paid attention to the first, that is, has drawn from research in psychological stress. Through our research questions, we suggest future research directions that focus on key IS-based concepts and relationships (involving the design and use of IS applications/devices) that constitute technostress. In doing so we advocate applying bodies of knowledge unique to the IS discipline including information systems management, design and use (Baskerville and Myers 2003) to the understanding of stress from IS use, and thus conceptually enrich the understanding of the stress phenomenon. Our framing thus embodies a cross-disciplinary attribution (Authors blinded, forthcoming) wherein we suggest that future research in technostress both draws from and informs the non-IS literatures (e.g. psychological stress and OB) that study stress in organizations. This is particularly important because although these 
literatures acknowledge the stress creating effects of IS, they do not explain how the phenomenon of stress is theoretically informed by the particularities of IS use, design or management (Hamborg and Greif 2009). We thus seek to guide future research in technostress in ways that would mutually enrich the cognate literatures in technostress (IS), and organizational behavior and psychological stress (non-IS).

Dark Side and Bright Side: Technostress is experienced differentially by the individual, depending on whether IS characteristics are appraised as challenge or threat stressors. Each kind of experience of stress has distinct appraisal and coping processes associated with it. Techno-eustress introduces a new theoretical aspect to the phenomenon of technostress by considering its positive aspects and outcomes. With the rise of the millennial work force, current (and future) employees are using (will use) IS in ways that previous generations did not (Vodanovich et al. 2010). They experience the possibilities of using technology in unexpected and innovative ways for executing work-life activities. Further, new forms of work arrangements have emerged over the past decade such as virtual teams, teleworking and hot-desking (Coovert et al. 2009). In order to make such arrangements effective it is important to understand how technology poses motivational challenges that can be potentially mastered to enhance work processes and outcomes. Going forward it is important to understand how individuals experience and react to the thrill and difficulty of new technologies for innovation, creativity and improved performance. We lay out research questions that need to be addressed for understanding techno-eustress and provide directions for such enquiry. In doing so, we provide a conceptually enhanced description of the technostress process that delineates both the positive and negative outcomes.

IS Design to Tackle Technostress: We show how, in addition to being a cause of techno-stress, use of IS can be a means to its mitigation. This is an argument for a new and unexplored theoretical role for IS in the phenomenon of technostress. Furthermore, and in line with our inter-disciplinary framing, it suggests a distinctive role for IS in tackling the phenomenon of stress from technology use, which can enrich the literature that studies stress, by contributing to it concepts relating to IS design. Developing this argument, we suggest that IS can be designed to deliver appropriate interventions for detecting, measuring and reducing (enhancing) the negative (positive) outcomes of techno-distress (techno-eustress). This line of research is quite uncharted. It offers scope for incorporating design science into technostress research, to investigate how applications, devices and wearables can be designed for measuring and monitoring technostress outcomes and providing adaptation cues, potentially in real time. Further, the possibility of measuring physiological outcomes offers 
methodological opportunities for integrating design science and neuro science within technostress research, to look at how applications, devices and wearables can be designed and developed for detecting and managing technostress. These embody new perspectives for the technostress literature. They are also of significance to the organizational stress literature which is beginning to acknowledge that IS can create stress, but does not identify coping and mitigation mechanisms facilitated by IS design and use. As Hamborg and Greif (2009, p. 225) suggest "the designs of workstations, hardware and software components are important factors related to stress".

Methods: The experience of techno-eustress and techno-distress is highly contextual. The appraisal of challenge and threat stressors, activation of coping responses, and the incidence of outcomes are determined by the specifics of the situation (Lazarus and Folkman 1984); their identification should be salient to the objectives, research questions and research setting of the technostress situation. Different constituents of the techno-eustress and techno-distress process thus lend themselves to different kinds of research designs and methods.

Behavioural measures are salient for assessing the subjective aspects of the stress process such as challenge and threat techno-stressors, as well as psychological and behavioural workplace outcomes associated with incidence of technostress such as, for example task innovation, problem solving, job satisfaction and burnout.

Neurological and physiological outcomes are in the form of the human body's biochemical and neuroendocrine parameters such as blood pressure, heart rate, respiration, galvanic skin response, adrenal cortical secretions, pupil dilation and brain activity (Lazarus 1966). They have been considered in the study of technostress (Galluch et al 2015; Riedl et al. 2012; Riedl et al. 2012; Tams et al. 2015). A few considerations are important in their measurement. One, they are highly subject to effects of individual-specific factors such as age, gender, diet, genetics, physical health, work-family environment, lifestyle etc; thus appropriate controls should be applied. They also tend to vary with the time of day and conditions such as room temperature and humidity; as such they may need to be measured many times (Bono et al. 2013). Two, they vary with the short-term or long-term incidence of stress. The former is associated with blood pressure and hormones, while the latter with markers such as ulcers (Bailey and Bhagat 1987; Bono et al. 2013). Three, many neurological and physiological markers such as salivary measurements of enzymes/hormones, blood pressure, heart rate, skin conductivity and fMRI scans are associated with both eustress and distress (Lazarus 1966; Selye 1974). That is, the stressors may be different, yet they produce the same biological response. Galluch et al (2015) found a lack of correspondence between 
behavioural (techno - distress) and physiological (hypothesized as distress-related) outcomes. This could be because the respondents were actually experiencing eustress, in which case the techno - distress related behavioural outcome would not be present, but the physiological outcome would be. Disagreement among measures is a possible indication of intervening processes that may not have been studied.

Objective and unobtrusive system measures, which can be drawn off a system's or device's logs without the individual being aware of it, are particularly relevant for measuring technology characteristics, such as availability, interruptions and presentism, and outcomes such as system use. Such measures eliminate individual subjectivities present in physiological measures and possibly biased recall in self-reported measures (Bailey and Bhagat 1987).

Given the plethora of possible outcomes studied in the stress literature, it is important that they should be theorized relate closely to the specific technostress situation - i.e. to the combination of tasks, IS applications and occupational particulars - to reveal the distinctive nature of techno-eustress and techno-distress related consequences. Further, triangulation of outcomes of different types can provide greater theoretical and empirical validity.

We next come to the issue of research design. Cross sectional research in technostress has been helpful in revealing different constructs and their associations. Longitudinal research designs are appropriate for measuring a number of dynamic aspects of the techno-distress and techno-eustress processes, such as the relationship between coping responses and their effects (Litt et al. 2011). Such designs need not span several days or months; they could span the duration of a day, and can aggregate findings of stressful IS use situations and responses to them over multiple daily measurements through surveys and diary studies (Bono et al. 2013; Litt et al. 2011; Maier et al 2015). Experimental design methods are appropriate for measuring episodic instances of techno-eustress and techno-distress such as interruptions (Galluch et al. 2015), multi-tasking and system related matters. Such designs offer tight control over the research setting; however they limited in the extent to which they can simulate real world situations of technostress where a number of emergent, situated and simultaneous factors (e.g. information processing, tasks, organizational norms and policies, individual reactions, workplace relationships) are at play.

Boundary Conditions: Finally, we note a few boundary conditions for our exposition. First, we focus primarily on the workplace, given the remarkably enduring importance of workplace stress (Cooper and Dewe 2004) and the role of IS in contributing to that (Ayyagari et al 2011; Tarafdar et al 2011). The pervasiveness of IS in the non-work context (e.g. social media, online shopping, home assistants such as Amazon's Echo) prompts us to consider if 
our framing is transferable therein. Similar to stress, Techno-Eustress and Techno-Distress are constitutive of both specific and non-specific aspects. Thus, the broad concepts we suggest in Figure 2 would remain relevant. That is, there would be demands from IS, which would be appraised as challenging or threatening, triggering coping responses and leading to outcomes. However, the preoccupation of the particulars would be different. For instance, the challenge and threat techno-stressors will be different for online shopping applications than they would be for enterprise applications. Or, outcomes such as reduced job satisfaction would become irrelevant for social media applications. Instead the quality of social relationships, emotions such as envy, or neo-luddism might become salient (e.g. Krasnova et al 2015; Moody and Galletta 2015). Thus the specific research questions and hence the potential directions of enquiry would be different, and would draw on literatures outside the management and organizational domains. Second, like any literature review, ours is bounded by the time period it covers. The directions for enquiry we suggest are thus not comprehensive; as new technologies emerge, new research directions would, as well.

In conclusion, technostress is a rich and complex phenomenon. Our (re)framing for future research, thus necessarily covers a number of aspects. Yet, it is also a fledgling and rapidly growing phenomenon. Existing literature provides a good foundation and starting point for going forward. We see it as important to take stock of current understanding and focus the thrust and efforts of future research on novel, less-understood, conceptually underresearched, and practically relevant areas.

\section{REFERENCES}

Agarwal, R., and Prasad, J. 1998. "A conceptual and operational definition of personal innovativeness in the domain of information technology," Information systems research (9:2), pp. 204-215.

Aiello, J. R., and Kolb, K. J. 1995. "Electronic Performance Monitoring and Social Context: Impact on Productivity and Stress," Journal of Applied Psychology (80:3), pp. 339353.

Alter, S. 2008. "Defining Information Systems as Work Systems: Implications for the IS Field," European Journal of Information Systems (17:5), pp. 448-469.

Alter, S. 2010. "Designing and Engineering for Emergence: A Challenge for HCI Practice and Research," AIS Transactions on Human-Computer Interaction (2:4), pp. 127140.

Amabile, T. M., Conti, R., Coon, H., Lazenby, J., and Herron, M. 1996. "Assessing the work environment for creativity," Academy of management journal (39:5), pp. 1154-1184. 
Authors blinded (forthcoming), Research in Information Systems: Intra-disciplinary and Inter-disciplinary Approaches, Journal of the AIS

Ayyagari, R., Grover, V., and Purvis, R. 2011. "Technostress: Technological Antecedents and Implications," MIS Quarterly (35:4), pp. 831-858.

Bala, H., and Venkatesh, V. 2015. "Adaptation to Information Technology: A Holistic Nomological Network from Implementation to Job Outcomes," Management Science (62:1), pp. 156-179.

Bailey, J. M., \& Bhagat, R. S. 1987. "Meaning and measurement of stressors in the work environment," in Stress and health: Issues in research methodology. S. V. Kasl and C. L. Cooper (eds.), Chichester, England: Wiley, pp. 207-230.

Barber, L. K., and Santuzzi, A. M. 2015. "Please Respond ASAP: Workplace Telepressure and Employee Recovery," Journal of Occupational Health Psychology (20:2), pp. $172-189$.

Barki, H., Titah, R., and Boffo, C. 2007. "Information System Use - Related Activity: An Expanded Behavioral Conceptualization of Individual-Level Information System Use," Information Systems Research (18:2), pp. 173-192.

Barley, S. R., Meyerson, D. E., and Grodal, S. 2011. "E-mail as a Source and Symbol of Stress," Organization Science (22:4), pp. 887-906.

Baskerville, R. L., and Myers, M. D. 2002. "Information Systems as a Reference Discipline," MIS Quarterly (26:1), pp. 1-14.

Beas, M. I., and Salanova, M. 2006. "Self-efficacy beliefs, computer training and psychological well-being among information and communication technology workers," Computers in Human Behavior (22:6), pp. 1043-1058.

Beaudry, A., and Pinsonneault, A. 2005. "Understanding User Responses to Information Technology: A Coping Model of User Adaptation,” MIS Quarterly (29:3), pp. 493524.

Beaudry, A., and Pinsonneault, A. 2010. "The Other Side of Acceptance: Studying the Direct and Indirect Effects of Emotions on Information Technology Use, " MIS Quarterly, (34:4), pp. 689-710.

Berry, C. M., Ones, D. S., and Sackett, P. R. 2007. "Interpersonal deviance, organizational deviance, and their common correlates: A review and meta-analysis," Journal of Applied Psychology (92:2), pp. 410-424.

Bolger, N., and Zuckerman, A. 1995. "A framework for studying personality in the stress process," Journal of personality and social psychology (69:5), pp. 890-902.

Boswell, W. R., and Olson-Buchanan, J. B. 2007. "The use of communication technologies after hours: The role of work attitudes and work-life conflict," Journal of Management (33:4), pp. 592-610.

Brown, R., Duck, J., and Jimmieson, N. 2014. "E-mail in the Workplace: The Role of Stress Appraisals and Normative Response Pressure in the Relationship Between E-mail Stressors and Employee Strain," International Journal of Stress Management (21:4), pp. 325-347.

Campbell, A., and Pisterman, S. 1996. "A fitting approach to interactive service design: The importance of emotional needs," Design Management Journal (Former Series) (7:4), pp. 10-14. 
Cavanaugh, M.A., Boswell, W.R., Roehling, M.V., and Boudreau, J.W. 2000. "An Empirical Examination of Self-Reported Work Stress among U.S. Managers," Journal of Applied Psychology (85:1), pp. 65-74.

Chang, E. C. 1998. "Dispositional optimism and primary and secondary appraisal of a stressor: Controlling for confounding influences and relations to coping and psychological and physical adjustment.," Journal of Personality and Social Psychology (74:4), pp. 1109-1120.

Chen, S., Westman, M., and Eden, D. 2009. "Impact of enhanced resources on anticipatory stress and adjustment to new information technology: A field-experimental test of conservation of resources theory," Journal of Occupational Health Psychology (14:3), pp. 219-230.

Compeau, D. R., and Higgins, C. A. 1995. "Computer Self-Efficacy: Development of a Measure and Initial Test," MIS Quarterly (19:2), pp. 189-211.

Cooper, C. L., Dewe, P. J., and O'Driscoll, M. P. 2001. Organizational stress: A review and critique of theory, research, and applications, SAGE Publications.

Cooper, C. L., \& Dewe, P. J. 2008. Stress: A brief history. Oxford: John Wiley \& Sons.

Coovert, M. D., Thompson, L. F., and Craiger, J. P. 2005. "Technology," in Handbook of work stress. J. Barling, E. K. Kelloway, and M. R. Frone (eds.), Thousand Oaks, CA: Sage, pp. 229-234.

Coovert, M. D., Ashley, A. G., Walvoord, A. A. G., Stilson, F. R. B., and Prewett, M. S. 2009. "Technology and Health," in The Oxford handbook of organizational wellbeing. S. Cartwright and C. L. Cooper (eds.), Oxford: Oxford University Press.

Crawford, E.R., LePine, J.A., and Rich, B.L. 2010. "Linking Job Demands and Resources to Employee Engagement and Burnout: A Theoretical Extension and Meta-Analytic Test," Journal of Applied Psychology (95:5), pp. 834-848.

D'Arcy, J., Herath, T., and Shoss, M. K. 2014. "Understanding Employee Responses to Stressful Information Security Requirements: A Coping Perspective," Journal of Management Information Systems (31:2), pp. 285-318.

Day, A., Paquet, S., Scott, N., and Hambley, L. 2012. "Perceived information and communication technology (ICT) demands on employee outcomes: The moderating effect of organizational ICT support.," Journal of occupational health psychology (17:4), pp. 473-491.

Dennison, L., Morrison, L., Conway, G., and Yardley, L. 2013. "Opportunities and challenges for smartphone applications in supporting health behavior change: qualitative study," Journal of medical Internet research (15:4).

Derrick, D. C., Jenkins, J. L., and Nunamaker Jr, J. F. 2011. "Design principles for special purpose, embodied, conversational intelligence with environmental sensors (SPECIES) agents," AIS Transactions on Human-Computer Interaction (3:2), pp. 6281.

DeSanctis, G., and Poole, M. S. 1994. "Capturing the complexity in advanced technology use: Adaptive structuration theory," Organization science (5:2), pp. 121-147.

Diaz, I., Chiaburu, D. S., Zimmerman, R. D., and Boswell, W. R. 2012. "Communication technology: Pros and cons of constant connection to work," Journal of Vocational Behavior (80:2), pp. 500-508. 
Doll, W. J., and Torkzadeh, G. 1989. "A discrepancy model of end-user computing involvement," Management Science (35:10), pp. 1151-1171.

Eurofound and the International Labour Office. 2017. Working anytime, anywhere: The effects on the world of work, Publications Office of the European Union, Luxembourg, and the International Labour Office, Geneva.

Fairweather, N. B. 1999. "Surveillance in employment: The case of teleworking," Journal of Business Ethics (22:1), pp. 39-49.

Fay, D., Sonnentag, S., and Frese, M. 1998. "Stressors, innovation, and personal initiative: Are stressors always detrimental," in Theories of organizational stress. C. L. Cooper, (ed.), Oxford University Press, pp. 170-189.

Fenlason, K. J., and Beehr, T. A. 1994. "Social support and occupational stress: Effects of talking to others," Journal of organizational behavior (15:2), pp. 157-175.

Fenner, G. H., and Renn, R. W. 2010. "Technology-assisted supplemental work and work-tofamily conflict: The role of instrumentality beliefs, organizational expectations and time management," Human Relations (63:1), pp. 63-82.

Fogg, B. J. 2003. Persuasive Technology: Using Computers to Change what We Think and Do, Amsterdam: Morgan Kaufmann.

Folkman, S. 2011. "Stress, Health, and Coping: Synthesis, Commentary, and Future Directions," in The Oxford Handbook of Stress, Health and Coping. S. Folkman (ed.), Oxford: Oxford University Press, pp. 453-462.

Folkman, S., Lazarus, R. S., Dunkel-Schetter, C., DeLongis, A., and Gruen, R. J. 1986. "Dynamics of a stressful encounter: Cognitive appraisal, coping, and encounter outcomes," Journal of personality and social psychology, (50:5), pp. 992-1003.

Fuglseth, A. M., and Sørebø, Ø. 2014. "The effects of technostress within the context of employee use of ICT," Computers in Human Behavior (40), pp. 161-170.

Galluch, P. S., Grover, V., and Thatcher, J. B. 2015. "Interrupting the Workplace: Examining Stressors in an Information Technology Context," Journal of the Association for Information Systems (16:1), pp. 1-47.

Gerling, K. M., Schulte, F. P., and Masuch, M. 2011. "Designing and evaluating digital games for frail elderly persons," in Proceedings of the 8th international conference on advances in computer entertainment technology, Lisbon, Portugal: ACM, p. 62.

Goldberg, L. R. 1990. "An alternative" description of personality': the big-five factor structure," Journal of personality and social psychology (59:6), pp. 1216-1229.

Guzella, T. S., \& Caminhas, W. M. 2009. "A review of machine learning approaches to spam filtering," Expert Systems with Applications (36:7), pp. 10206-10222.

Hamborg, K.-C., and Greif, S. 2009. "New technologies and stress," in The Handbook of Work and Health Psychology. C. L. Cooper, J. C. Quick, and M. J. Schabracq (eds.), John Wiley \& Sons, pp. 209-236.

Helgeson, V. S., Reynolds, K. A., and Tomich, P. L. 2006. "A meta-analytic review of benefit finding and growth," Journal of consulting and clinical psychology, (74:5), pp. 797-816.

Janis, I. L. 1977. “Adaptive Personality Changes," in Stress and coping: An anthology. A. Monat and R. S. Lazarus (eds.), New York, NY, USA: Columbia University Press. 
Jasperson, J. S., Carter, P. E., and Zmud, R. W. 2005. “A comprehensive conceptualization of post-adoptive behaviors associated with information technology enabled work systems," MIS Quarterly (29:3), pp. 525-557.

Johnson, D., and Wiles, J. 2003. "Effective affective user interface design in games," Ergonomics (46:13-14), pp. 1332-1345.

Kahn, R., and Byosiere, P. 1992. "Stress in organizations," in M. D. Dunnette, and L. M. Hough (eds.) Handbook of industrial and organizational psychology (2nd ed.),vol. 3, Palo Alto: Consulting Psychologists Press, pp. 571-650.

Kappos, A., and Rivard, S. 2008. "A Three-Perspective Model of Culture, Information Systems, and Their Development and Use," MIS Quarterly (32:3), pp. 601-634.

Kobasa, S. C. 1979. "Stressful life events, personality, and health: an inquiry into hardiness," Journal of personality and social psychology (37:1), pp. 1-11.

Kokkalis, N., Köhn, T., Pfeiffer, C., Chornyi, D., Bernstein, M.S. and Klemmer, S.R. 2013. EmailValet: managing email overload through private, accountable crowdsourcing," Proceedings of the 2013 Conference on Computer Supported Cooperative Work, ACM, San Antonio, TX, February 23-27, pp. 1291-1300.

Korunka, C., and Vitouch, O. 1999. "Effects of the implementation of information technology on employees' strain and job satisfaction: a context-dependent approach," Work \& Stress (13:4), pp. 341-363.

Krasnova, H., Widjaja, T., Buxmann, P., Wenninger, H., and Benbasat, I. 2015 "Why following friends can hurt you: An exploratory investigation of the effects of envy on social networking sites among college-age users," Information Systems Research (26: 3), pp. 585-605.

Kuonanoja, L., Langrial, S., Lappalainen, R., Lappalainen, P., and Oinas-Kukkonen, H. 2015. "Treating depression with a behavior change support system without face-to-face therapy," AIS Transactions on Human-Computer Interaction (7:3), pp. 192-210.

Lauriola, M., and Levin, I. P. 2001. "Relating individual differences in attitude toward ambiguity to risky choices," Journal of Behavioral Decision Making (14:2), pp. 107122.

Lazarus, R. S. 1966. Psychological stress and the coping process, New York, NY, USA: McGraw-Hill.

Lazarus, R. S., and Folkman, S. 1984. Stress, appraisal, and coping, New York, NY, USA: Springer publishing company.

Leidner, D. E., and Kayworth, T. 2006. "Review: A Review of Culture in Information Systems Research: Toward a Theory of Information Technology Culture Conflict," MIS Quarterly (30:2), pp. 357-399.

Le Fevre, M., Matheny, J., and Kolt, G. S. 2003. "Eustress, distress, and interpretation in occupational stress," Journal of Managerial Psychology (18:7), pp. 726-744.

Leung, L. 2011. "Effects of ICT connectedness, permeability, flexibility, and negative spillovers on burnout and job and family satisfaction," Human Technology (7:3), pp. 250-267.

Lim, V. K. 1996. "Job insecurity and its outcomes: Moderating effects of work-based and nonwork-based social support," Human relations (49:2), pp. 171-194. 
Litt, D., Tennen, H., Affleck, G. 2011. "The Dynamics of Stress, Coping, and Health: Assessing Stress and Coping Processes in Near Real Time," in The Oxford Handbook of Stress, Health and Coping. S. Folkman (ed.), Oxford: Oxford University Press, pp. 387-406.

Lundberg, U., and Cooper, C. L. 2011. The science of occupational health: stress, psychobiology, and the new world of work, Oxford: John Wiley \& Sons.

Maier, C., Laumer, S., Eckhardt, A., and Weitzel, T. 2014. "Giving too much social support: social overload on social networking sites," European Journal of Information Systems (24:5), pp. 1-18.

Maier, C., Laumer, S., Weinert, C., and Weitzel, T. 2015. "The effects of technostress and switching stress on discontinued use of social networking services: A study of Facebook use," Information Systems Journal (25:3), pp. 275-308.

Majchrzak, A., and Cotton, J. 1988. "A longitudinal study of adjustment to technological change: From mass to computer-automated batch production," Journal of Occupational Psychology (61:1), pp. 43-66.

Majchrzak, A., Rice, R. E., Malhotra, A., King, N., and Ba, S. 2000. "Technology adaptation: The case of a computer-supported inter-organizational virtual team," MIS quarterly (24:4), pp. 569-600.

Mazmanian, M., Orlikowski, W. J., and Yates, J. 2013. "The Autonomy Paradox: The Implications of Mobile Email Devices for Knowledge Professionals," Organization Science (24:5), pp. 1337-1357.

McGrath, J. E. 1976. "Stress and behavior in organizations," in Handbook of industrial and organizational psychology. M. D. Dunnette (ed.), Chicago: Rand McNally.

Miller, S., and Weckert, J. 2000. "Privacy, the Workplace and the Internet," Journal of Business Ethics (28:3), pp. 255-265.

Moody, G. D., and Galletta, D. F. 2015. "Lost in cyberspace: The impact of information scent and time constraints on stress, performance, and attitudes online," Journal of Management Information Systems (32:1), pp. 192-224.

Murphy, L. B. 1962. The widening world of childhood, paths toward mastery, New York, NY, USA: Basic Books.

Nelson, D. L., and Kletke, M. G. 1990. "Individual adjustment during technological innovation: A research framework," Behaviour \& Information Technology (9:4), pp. 257-271.

O'Driscoll, M. P., Brough, P., Timms, C., and Sawang, S. 2010. "Engagement with information and communication technology and psychological well-being," in New developments in theoretical and conceptual approaches to job stress. Research in occupational stress and well-being. P. L. Perrewé and D. C. Ganster (eds.), London: Emerald Group Publishing, pp. 269-316.

Ohly, S., and Latour, A. 2014. "Work-Related Smartphone Use and Well-Being in the Evening: The Role of Autonomous and Controlled Motivation," Journal of Personnel Psychology (13:4), pp. 174-183.

Oinas-Kukkonen, H., and Harjumaa, M. 2009. "Persuasive systems design: Key issues, process model, and system features," Communications of the Association for Information Systems (24:1), pp. 485-500. 
Orlikowski, W. J. 1992. "The duality of technology: Rethinking the concept of technology in organizations," Organization science (3:3), pp. 398-427.

Orlikowski, W. J., and Barley, S. R. 2001. "Technology and Institutions: What Can Research on Information Technology and Research on Organizations Learn from Each Other?," MIS Quarterly (25:2), pp. 145-165.

Orlikowski, W. J., and Gash, D. C. 1994. "Technological frames: making sense of information technology in organizations," ACM Transactions on Information Systems (TOIS) (12:2), pp. 174-207.

Ortiz de Guinea, A. 2016. "A pragmatic multi-method investigation of discrepant technological events: Coping, attributions, and 'accidental' learning," Information \& Management (53:6), pp. 787-802.

Pakenham, K. I. 2011. "Benefit-finding and sense-making in chronic illness," in S. Folkman (Ed.), The Oxford handbook of stress, health, and coping, NY: Oxford University Press, pp. 242-268.

Pearlin, Leonard I., Elizabeth G. Menaghan, Morton A. Lieberman, and Joseph T. Mullan. 1981. "The Stress Process," Journal of Health and Social Behavior (22:4), pp. 337356.

Ragu-Nathan, T. S., Tarafdar, M., Ragu-Nathan, B. S., and Qiang Tu. 2008. "The Consequences of Technostress for End Users in Organizations: Conceptual Development and Empirical Validation," Information Systems Research (19:4), pp. 417-433.

Reinke, K., and Chamorro-Premuzic, T. 2014. "When email use gets out of control: Understanding the relationship between personality and email overload and their impact on burnout and work engagement," Computers in Human Behavior (36), pp. 502-509.

Riedl, R. 2013. "On the Biology of Technostress: Literature Review and Research Agenda," SIGMIS Database (44:1), pp. 18-55.

Riedl, R., Kindermann, H., Auinger, A., \& Javor, A. 2012. "Technostress from a Neurobiological Perspective," Business \& Information Systems Engineering (4:2), pp. 61-69.

Ryan, R. M., and Deci, E. L. 2000. "Self-determination theory and the facilitation of intrinsic motivation, social development, and well-being.," American psychologist (55:1), pp. $68-78$.

Salanova, M., Llorens, S., and Cifre, E. 2013. "The dark side of technologies: Technostress among users of information and communication technologies," International Journal of Psychology (48:3), pp. 422-436.

Salanova, M., Llorens, S., and Ventura, M. 2014. "Technostress: The Dark Side of Technologies," in The Impact of ICT on Quality of Working Life. C. Korunka and P. Hoonakker (eds.), Springer, pp. 87-103.

Schaubroeck, J., and Merritt, D. E. 1997. "Divergent effects of job control on coping with work stressors: The key role of self-efficacy," Academy of Management Journal (40:3), pp. 738-754.

Seligman, M. E., and Csikszentmihalyi, M. 2000. "Special issue on happiness, excellence, and optimal human functioning," American Psychologist (55:1), pp. 5-183. 
Selye, H. 1956. The stress of life, New York, NY, USA: McGraw-Hill.

Selye, H. 1974. Stress without Distress, Philadelphia: Lippincott.

Singletary, L., Akbulut, A., and Houston, A. 2002. "Unanticipated software use by adolescents following mandatory adoption," ICIS 2002 Proceedings.

Skinner, E. A., and Zimmer-Gembeck, M. J. 2011. "Perceived control and the development of coping," in The Oxford Handbook of Stress, Health and Coping. S. Folkman (ed.), Oxford: Oxford University Press, pp. 35-59.

Soucek, R., and Moser, K. 2010. "Coping with information overload in email communication: Evaluation of a training intervention," Computers in Human Behavior (26:6), pp. 1458-1466.

Spector, P. E., Zapf, D., Chen, P. Y., Frese, M., and others. 2000. "Why negative affectivity should not be controlled in job stress research: Don't throw out the baby with the bath water," Journal of Organizational Behavior (21:1), pp. 79-95.

Sprigg, C. A., and Jackson, P. R. 2006. "Call Centers as Lean Service Environments: JobRelated Strain and the Mediating Role of Work Design," Journal of Occupational Health Psychology (11:2), pp. 197-212.

Srivastava, S. C., Chandra, S., and Shirish, A. 2015. "Technostress creators and job outcomes: theorising the moderating influence of personality traits," Information Systems Journal (25:4), pp. 355-401.

Stanton, J. M., and Weiss, E. M. 2000. "Electronic monitoring in their own words: an exploratory study of employees' experiences with new types of surveillance," Computers in Human Behavior (16:4), pp. 423-440.

Stein, M.-K., Newell, S., Wagner, E. L., and Galliers, R. D. 2015. "Coping with Information Technology: Mixed Emotions, Vacillation, and Nonconforming Use Patterns," Mis Quarterly (39:2), pp. 367-392.

Sun, H. 2012. "Understanding user revisions when using information system features: Adaptive system use and triggers," MIS quarterly (36:2), pp. 453-478.

Sutherland, V. J., and Cooper, C. L. 1990. Understanding stress: A psychological perspective for health professionals, Chapman \& Hall/CRC.

Sykes, T. A. 2015. "Support Structures and Their Impacts on Employee Outcomes: A Longitudinal Field Study of an Enterprise System Implementation," MIS Quarterly (39:2), pp. 473-A11.

Tams, S., Hill, K., de Guinea, A. O., Thatcher, J., and Grover, V. 2014. "NeuroISAlternative or Complement to Existing Methods? Illustrating the Holistic Effects of Neuroscience and Self-Reported Data in the Context of Technostress Research," Journal of the Association for Information Systems (15:10), pp. 723-753.

Tarafdar, M., Qiang Tu, Ragu-Nathan, B. S., and Ragu-Nathan, T. S. 2007. "The Impact of Technostress on Role Stress and Productivity," Journal of Management Information Systems (24:1), pp. 301-328.

Tarafdar, M., Tu, Q., and Ragu-Nathan, T. S. 2010. "Impact of Technostress on End-User Satisfaction and Performance," Journal of Management Information Systems (27:3), pp. 303-334. 
Tarafdar, M., Tu, Q., Ragu-Nathan, T. S., and Ragu-Nathan, B. S. 2011. "Crossing to the dark side: examining creators, outcomes, and inhibitors of technostress," Communications of the ACM (54:9), pp. 113-120.

Tarafdar, M., Pullins, E. B., and Ragu-Nathan, T. S. 2015. "Technostress: negative effect on performance and possible mitigations," Information Systems Journal (25:2), pp. 103132.

ter Hoeven, C. L., \& van Zoonen, W. 2015. "Flexible work designs and employee well-being: examining the effects of resources and demands." New Technology, Work and Employment, 30(3), 237-255.

Vodanovich, S., Sundaram, D., and Myers, M. 2010. "Research commentary-Digital natives and ubiquitous information systems," Information Systems Research (21:4), pp. 711723.

Wajcman, J., and Rose, E. 2011. "Constant Connectivity: Rethinking Interruptions at Work," Organization Studies (32:7), pp. 941-961.

Webster, J., and Watson, R. T. 2002. "Analyzing the past to prepare for the future: Writing a literature review," Management Information Systems Quarterly (26:2), p. 3.

Weiser, M., and Brown, J. S. 1997. "The coming of age of calming technology," in Beyond calculation: the next fifty years of computing. P. J. Denning and R. M. Metcalfe (eds.), New York, NY, USA: Springer-Verlag, pp. 75-86.

Yan, Z., Guo, X., Lee, M. K. O., and Vogel, D. R. 2013. "A conceptual model of technology features and technostress in telemedicine communication," Information Technology \& People (26:3), pp. 283-297.

Yim, J., and Graham, T. C. 2007. "Using games to increase exercise motivation," in Proceedings of the 2007 conference on Future Play, New York, NY, USA: ACM, pp. 166-173.

Zhang, S., Zhao, L., Lu, Y., and Yang, J. 2016. "Do you get tired of socializing? An empirical explanation of discontinuous usage behaviour in social network services," Information \& Management (53:7), pp. 904-914.

Zorn, T. E. 2003. "The emotionality of information and communication technology implementation," Journal of Communication Management (7:2), pp. 160-171.

Zuboff, S. 1988. In the age of the smart machine: The future of work and power, New York, NY, USA: Basic books.

Zuboff, S. 2015. "Big other: surveillance capitalism and the prospects of an information civilization," Journal of Information Technology (30:1), pp. 75-89. 


\section{APPENDICES}

\section{Appendix A: Methods for Literature Review}

This section presents the methods for our review of the literature that addresses stress due to use of IS. Specifically, it describes how the corpus of articles was collected, selected and reviewed, based on guidelines provided by Webster and Watson (2002). The process is summarized in Table A1 below.

Table A1. Summary of the Review Method

\begin{tabular}{|c|c|c|}
\hline Stage & Activity & Description \\
\hline 1 & $\begin{array}{l}\text { Selection of disciplinary corpus } \\
\text { for article review }\end{array}$ & $\begin{array}{l}\text { Information Systems (IS), non-IS [ Organizational Behavior } \\
\text { (OB), Psychological Stress (Stress)] }\end{array}$ \\
\hline 2 & $\begin{array}{l}\text { Selection of keywords and } \\
\text { design of search queries }\end{array}$ & $\begin{array}{l}\text { Keywords searched for in article titles, abstracts and keywords. } \\
\text { See Table } 2\end{array}$ \\
\hline 3 & Selection of journals for query & See Table 2 \\
\hline \multirow[t]{3}{*}{4} & Query runs & $\begin{array}{l}\text { Queries ran on the EBSCO engine using the databases } \\
\text { Academic Search Complete, Psyclnfo, and Business Source } \\
\text { Premier. The date of the query was April } 21,2017 \text {. }\end{array}$ \\
\hline & & $\begin{array}{l}\text { - IS Query: } 117 \text { articles retrieved } \\
\text { - Non IS Query: } 66 \text { articles retrieved } \\
\circ \text { OB Query: } 15 \text { articles retrieved } \\
\circ \quad \text { Stress Query: } 50 \text { articles retrieved } \\
\text { - Total: } 182 \text { articles retrieved } \\
\text { Results were imported in a reference management software. }\end{array}$ \\
\hline & & $\begin{array}{l}\text { Email alerts and RSS feeds were set up to retrieve future } \\
\text { publications which were also included. }\end{array}$ \\
\hline 5 & $\begin{array}{l}\text { Rejection of articles that were } \\
\text { not about technology -related } \\
\text { stress, strain, coping or } \\
\text { appraisal }\end{array}$ & $\begin{array}{l}\text { - } \quad \text { IS Query: } 103 \text { articles rejected (14 retained) } \\
\text { - Non-IS Query: } 58 \text { articles rejected (8 retained) } \\
\circ \quad \text { OB Query: } 15 \text { articles rejected (1 retained) } \\
\circ \quad \text { Stress Query: } 43 \text { articles rejected (7 retained) } \\
\text { - Total: } 160 \text { articles rejected (22 retained) } \\
\end{array}$ \\
\hline \multirow[t]{3}{*}{6} & Backward and forward search & $\begin{array}{l}\text { Articles cited in the articles initially retrieved (i.e. } \\
\text { backward search): } 2 \text { additional articles }\end{array}$ \\
\hline & & $\begin{array}{l}\text { - Articles having cited the articles initially retrieved (i.e. } \\
\text { forward search): } 3 \text { additional articles }\end{array}$ \\
\hline & & - Total: 5 additional articles \\
\hline \multirow[t]{2}{*}{7} & Classification of articles & See Table 1 and Appendix Table C \\
\hline & Total & 27 articles in the review corpus \\
\hline
\end{tabular}

Selection of disciplinary corpus: First, we selected the disciplinary corpus that would form the focus of our search. Given the nature of the phenomenon of technostress, it was important to cover journals from the relevant fields. Studies of psychological stress in 
organizational settings have been reported in journals from the organizational behavior (OB), psychological stress and related disciplines. The phenomenon of technostress has been studied in the IS discipline. Our search for relevant papers therefore covers articles from these disciplines.

Selection of keywords: We find that each of these disciplines has its own distinct lexicon for describing stress from use of IS. Articles in OB and psychological stress journals mention stress due to information and communication technologies but not 'technostress', which is more widely attributed in the IS discipline. On the contrary, keywords that capture Information Systems (IS) or Information Technology (IT) or Information and Communication Technology (ICT) may not be relevant or helpful for articles from IS journals due their disciplinary focus. As a result, we ran separate investigations for each discipline, with the query for each investigation having a distinct and different set of keywords, as shown in Table A2. For the IS journals, we searched for articles containing either technostress-related keywords or simply stress-related keywords. We used both the keywords 'techno*' and 'stress*' (i.e. 'technostress', 'technological stress', 'technostressor' etc.). As IS articles are likely to be related to technology already, we also considered articles containing simply the keywords 'strain', 'coping', or 'stress*' (i.e. 'stress', 'stressor', 'stressful' etc.). Such queries would, for instance, capture articles on stress that individuals experience related to IS use or implementation, although such articles may not have used the words 'technostress'. For the OB and psychological stress journals, due to their disciplinary focus, it would be irrelevant to search for articles containing the keyword 'stress' but not 'technology'. These journals primarily focus on work structures and arrangements enabled by technology such as teleworking and virtual work, as well as on widely used office communication applications such as email. We thus required articles in these journals to contain both a stress-related keyword (stress*, strain or coping) and a technology-related keyword. The technology-related keywords included technology, ICT, teleworking, email or virtual work. 
Table A2. Corpus of Journals for the Review

\begin{tabular}{|c|c|c|}
\hline Discipline & Journal & Query \\
\hline $\begin{array}{l}\text { Information } \\
\text { Systems }\end{array}$ & $\begin{array}{l}\text { European Journal of Information Systems } \\
\text { Information and Management } \\
\text { Information Systems Journal } \\
\text { Information Systems Research } \\
\text { Journal of the Association for Information } \\
\text { Systems } \\
\text { Journal of Information Technology } \\
\text { Journal of Management Information Systems } \\
\text { Journal of Strategic Information Systems } \\
\text { Management Science } \\
\text { MIS Quarterly } \\
\text { Computers in Human Behavior * } \\
\text { Information Technology and People* }\end{array}$ & $\begin{array}{c}\text { (techno* AND stress }^{*} \text { ) OR stress } \\
\text { OR strain OR coping }\end{array}$ \\
\hline $\begin{array}{l}\text { Non Information } \\
\text { Systems (e.g. } \\
\text { Organizational } \\
\text { Behavior, } \\
\text { Psychological } \\
\text { Stress) }\end{array}$ & $\begin{array}{l}\text { Organization Science } \\
\text { Administrative Science Quarterly } \\
\text { Academy of Management Review } \\
\text { Academy of Management Journal } \\
\text { Organization Studies } \\
\text { Human Relations } \\
\text { Work and Stress } \\
\text { Stress and Health } \\
\text { Journal of Occupational Health Psychology } \\
\text { International Journal of Stress Management } \\
\text { Journal of Applied Psychology } \\
\text { Journal of Occupational Health Psychology } \\
\text { Personnel Psychology } \\
\text { Organizational Behavior \& Human Decision } \\
\text { Processes }\end{array}$ & $\begin{array}{l}\text { (techno* OR ICT OR telework* } \\
\text { OR telecommut* OR "e-mail" OR } \\
\text { electronic* OR "virtual work") } \\
\text { AND (stress* OR strain OR } \\
\text { coping) }\end{array}$ \\
\hline Total & 26 journals & \\
\hline
\end{tabular}

Selection of journals for the initial query run: We searched for the query-keywords in titles, abstracts and keywords of all articles published since 1995, to generate an approximately 20 year (1995-2016) horizon for our search. The starting year of 1995 is prior to the uptake of pervasive, mobile, multi-device and multi-application use of IS, which are key drivers of technostress. For each discipline, we selected the set of leading journals which 
allowed us to retrieve most major contributions in the starting query run (Webster and Watson, 2002). The full set of selected journals is presented in Table 2. For the IS discipline set, we selected journals based on (1) the AIS basket-of-eight journals, (2) journals previously searched for in review papers (e.g. Kappos and Rivard 2008), and (3) journals covered in the Financial Times (International), UT Dallas (US) and Association of Business Schools (UK) ranking lists. For the $\mathrm{OB}$ and psychological stress disciplines set, we selected journals based on (1) journals previously searched for in previous theory and review papers (e.g. Berry et al. 2007; Leidner and Kayworth 2006) and (2) journals present in the Financial Times (International), UT Dallas (US) and Association of Business Schools (UK) lists. We ran the queries on the EBSCO engine using the databases Academic Search Complete, PsycInfo, and Business Source Premier. 117 results were returned for the IS journals and 66 results for the non-IS journals. All the articles were retrieved, stored and managed through reference management software. Email alerts and RSS feeds were then created so that articles published after the search were automatically retrieved and considered for inclusion. We did not consider conferences because: the objectives of conferences vary widely across disciplines; conference papers may report on conceptually /empirically incomplete and untested material; conference papers typically would be published in journals eventually; and reviews in IS journals typically have not considered conferences.

Article selection from initial query run: We rejected articles that were not about technology-related stress, strain, coping or appraisal. For IS journals, 103 articles were rejected out of the 117 retrieved, leaving 14 valid articles. For non-IS journals, 58 articles were rejected out of the 66 retrieved, leaving 8 valid articles. A total of 22 articles were kept out of the 182 initially retrieved. The reasons for rejecting the articles are presented in Appendix B.

Backward and forward search on articles selected: Backward and forward search was used to retrieve a further set of relevant articles, based on the originally retained set from all the three. The backward search (i.e. articles having been cited) was conducted by analyzing the references of the articles initially selected. This resulted in 1 additional article. The forward search (i.e. articles having cited the initially retrieved articles) was conducted using the Web of Science search engine. The forward search returned 3 additional articles. The backward and forward searches were not confined to the journals previously selected. However the articles retrieved from them were published largely in the initial set of journals, with two additional journals, as shown in Table 2. In total, the review therefore contains 27 articles. 
Classification of articles: The final list of articles is presented in Appendices B and C. We find that the articles covered the following aspects of the phenomenon of stress: Technology environmental conditions, Techno-stressors, Outcomes, Coping Responses, and Moderators of the stressor-outcome relationship. Some of the articles covered additional aspects such as the moderators of the stressor-outcome relationship. We recorded all the contributions for each paper under appropriate labels. At the end of this step we produced two tables - Appendix $\mathrm{C}$ and Table 1 of the paper. The first tabulates each paper and identifies/checks the concept(s) that it covers. The second tabulates and describes each concept, as it emerged collectively from the papers in our corpus that covered it. 


\section{Appendix B: Methods for Literature Review: Papers Removed After Initial Screening}

\begin{tabular}{|c|c|c|}
\hline $\begin{array}{l}\text { Reasons for } \\
\text { removal }\end{array}$ & Articles removed & $\begin{array}{l}\text { Articles* }^{*} \\
\text { removed }\end{array}$ \\
\hline \multirow[t]{3}{*}{$\begin{array}{l}\text { Articles } \\
\text { containing a } \\
\text { keyword used } \\
\text { in a different } \\
\text { meaning (E.g., } \\
\text { verb "to } \\
\text { stress", } \\
\text { "electronic } \\
\text { survey"...) }\end{array}$} & $\begin{array}{l}\text { IS: (Abrahamsson, Conboy, \& Xiaofeng Wang, 2009), (Almklov, Østerlie, } \\
\text { \& Haavik, 2014), (Anderson, 2002), (Baskerville, 2009), (Baskerville, } \\
\text { 2012), (Bergman, Lyytinen, \& Mark, 2007), (Besanko, Dranove, \& } \\
\text { Shanley, 2001), (Ceccagnoli, Forman, Huang, \& Wu, 2012), (D. G. } \\
\text { Wastell, 1999), (D. Wastell \& White, 2010), (Daning Hu, Zhao, Zhimin } \\
\text { Hua, \& Wong, 2012), (Desouza, 2003), (El Sawy, Malhotra, YoungKi } \\
\text { Park, \& Pavlou, 2010), (Elitzur \& Wensley, 1997), (Elliot, 2011), (Garcia, } \\
\text { Renault, \& Tsafack, 2007), (Glasserman \& Wang, 2011), (Gupta \& } \\
\text { Srinivasan, 1998), (Hong \& Pavlou, 2014), (Hsu, Chu, Lin, \& Lo, 2014), } \\
\text { (Hutton, Danling, \& Kumar, 2015), (Karim, 2009), (Kettinger \& Yuan Li, } \\
\text { 2010), (Kuntz, Mennicken, \& Scholtes, 2015), (Ma, 2010), (Majchrzak, } \\
\text { 2009), (Mamani, Chick, \& Simchi-Levi, 2013), (Marlei MP Pozzebon \& } \\
\text { Eric Ev van Heck, 2006), (Matook, Cummings, \& Bala, 2015), (Moynihan, } \\
\text { 2002), (Mumford, 2006a), (Mumford, 2006b), (Niehaves \& Ortbach, } \\
\text { 2016), (Otim, Dow, Grover, \& Wong, 2012), (Paul, 2007), (Pavlou \& } \\
\text { Fygenson, 2006), (Puri, 2007), (Riemer \& Johnston, 2014), (Sias, Turtle, } \\
\text { \& Zykaj, 2016), (Scherer, Wünderlich, \& von Wangenheim, 2015), } \\
\text { (Schipper, 2015), (Schultze, 2012), (Sias, Turtle, \& Zykaj, 2016), } \\
\text { (Sterman \& Repenning, 1997), (Straub, 2008), (Theodora Ngosi \& } \\
\text { Ashley Braganza, 2009), (Thiesse, 2007), (Tractinsky \& Jarvenpaa, } \\
\text { 1995), (Von Hippel \& Katz, 2002), (Weber, 2004), (Westrup, 2012), } \\
\text { (Xiao-Bai Li \& Sarkar, 2014), (Yamin \& Gavious, 2013), (Yang, Birge, \& } \\
\text { Parker, 2015), (Younghwa Lee \& Larsen, 2009) }\end{array}$ & IS: 55 \\
\hline & $\begin{array}{l}\text { Non-IS: (Huff, 2001), (Kotsou, Nelis, Grégoire, \& Mikolajczak, 2011), } \\
\text { (Mantovani, 1995), (Marino, Aversa, Mesquita, \& Anand, 2015), (Mutch, } \\
\text { 2010), (Peters \& Heusinkveld, 2010), (Rodríguez-Sánchez, Schaufeli, } \\
\text { Salanova, Cifre, \& Sonnenschein, 2011), (Saxberg, 2003), } \\
\text { (Sonnenschein, Sorbi, van Doornen, Schaufeli, \& Maas, 2007), (Toh \& } \\
\text { Kim, 2013), (Prado \& Sapsed, 2016), (Rosenkopf \& Padula, 2008) }\end{array}$ & Non-IS: 12 \\
\hline & & Total: 67 \\
\hline \multirow[t]{2}{*}{ Editorials } & $\begin{array}{l}\text { IS: (Anonymous, 2011), (Anonymous, 2009), (Gorman, 2011), (Gorman, } \\
\text { 2012), (Gorman, 2015), (Straub \& Welke, 1998), (Tarafdar, Gupta, \& } \\
\text { Turel, 2013), (Tarafdar, Gupta, \& Turel, 2015) }\end{array}$ & IS: 8 \\
\hline & $\begin{array}{l}\text { Non-IS: (Anonymous, 1999), (DeLeon, Brown, \& Kupchella, 2003), } \\
\text { (Levy-Leboyer, 2003) }\end{array}$ & Non-IS: 3 \\
\hline
\end{tabular}




\begin{tabular}{|c|c|c|}
\hline & & Total: 11 \\
\hline \multirow{3}{*}{$\begin{array}{l}\text { Articles } \\
\text { researching } \\
\text { stress } \\
\text { experienced by } \\
\text { professionals } \\
\text { but not due to } \\
\text { use of IS (E.g., } \\
\text { stress due to } \\
\text { difficult working } \\
\text { hours and } \\
\text { schedules) }\end{array}$} & $\begin{array}{l}\text { IS: (Ahuja, Chudoba, Kacmar, McKnight, \& George, 2007), (Allen, } \\
\text { Armstrong, Reid, \& Riemenschneider, 2008), (Armstrong, } \\
\text { Riemenschneider, Allen, \& Reid, 2007), (Benamati \& Lederer, 1997), } \\
\text { (Benamati \& Lederer, 2001), (Chilton, Hardgrave, \& Armstrong, 2005), } \\
\text { (King \& Sethi, 1997), (LeRouge, Nelson, \& Blanton, 2006), (Moore, 2000) }\end{array}$ & \\
\hline & $\begin{array}{l}\text { Non-IS: (Innstrand, Langballe, \& Falkum, 2010), (Innstrand, Langballe, \& } \\
\text { Falkum, 2012), (Innstrand, Langballe, Espnes, Falkum, \& Aasland, } \\
\text { 2008), (Mantler, Matejicek, Matheson, \& Anisman, 2005), (Mauno, } \\
\text { Kinnunen, \& Ruokolainen, 2006), (Morimoto \& Shimada, 2015), (Stewart } \\
\text { \& Barling, 1996), (Syrek, Apostel, \& Antoni, 2013), (Van de Ven, van den } \\
\text { Tooren, \& Vlerick, 2013) }\end{array}$ & Non-IS: 9 \\
\hline & & 8 \\
\hline \multirow{3}{*}{$\begin{array}{l}\text { Articles that } \\
\text { were not about } \\
\text { technology and } \\
\text { thus not about } \\
\text { technostress } \\
\text { (E.g., telework } \\
\text { stress } \\
\text { unrelated to } \\
\text { technology, or } \\
\text { any kind of } \\
\text { stress } \\
\text { unrelated to } \\
\text { technology) }\end{array}$} & $\begin{array}{l}\text { IS: (Dahl, 2011), (Goh, Pfeffer, \& Zenios, 2016), (Kocher, Lenz, \& Sutter, } \\
\text { 2012), (Zahedi, Abbasi, \& Yan Chen, 2015) }\end{array}$ & \\
\hline & $\begin{array}{l}\text { Non-IS: (Biggs, Brough, \& Barbour, 2014), (Dettmers, Bamberg, \& } \\
\text { Seffzek 2016), (Elsbach \& Hargadon, 2006), (llies, Wilson, \& Wagner, } \\
\text { 2009), (Gajendran \& Harrison, 2007), (Gan, Gan, Chen, Miao, \& Zhang, } \\
\text { 2015), (Greenberg, Ashton-James, \& Ashkanasy, 2007), (Giuseffi et al., } \\
\text { 2011), (Hammer, Kossek, Bodner, \& Crain, 2013), (Hornung, Rousseau, } \\
\text { \& Glaser, 2008), (Kristensen, 1996), (Lapierre \& Allen, 2006), (Leslie, } \\
\text { Park, Mehng, \& Manchester, 2012), (Lundberg \& Lindfors, 2002), } \\
\text { (McIntyre, Mclntyre, Barr, Woodward, Francis, Durand, Mehta, \& } \\
\text { Kamarc, 2016), (Paškvan, Kubicek, Prem, \& Korunka, 2016), (Peeters, } \\
\text { de Jonge, Janssen, \& van der Linden, 2004), (Purser \& Park, 1995), } \\
\text { (Sonnentag, Binnewies, \& Mojza, 2008), (Tietze \& Musson, 2005), } \\
\text { (Villani, Riva, \& Riva, 2007), (Zeitlin, 1995) }\end{array}$ & Nor \\
\hline & & Total: 26 \\
\hline $\begin{array}{l}\text { Articles that } \\
\text { were about } \\
\text { technology but } \\
\text { not about } \\
\text { technostress } \\
\text { despite the use } \\
\text { of keywords } \\
\text { (E.g., } \\
\text { technology } \\
\text { impact on } \\
\text { sleep quality, } \\
\text { interruptions, }\end{array}$ & $\begin{array}{l}\text { IS: (Atkinson, Guetz, \& Wein, 2009), (Brinton Anderson, Vance, Kirwan, } \\
\text { Eargle, \& Jenkins, 2016), (Cameron, Webster, Barki, \& de Guinea, } \\
\text { 2016), (Chen \& Zahedi, 2016), (Chesney, Coyne, Logan, \& Madden, } \\
\text { 2009), (Compeau, Higgins, \& Huff, 1999), (Elie-Dit-Cosaque \& Straub, } \\
\text { 2011), (George, 1996), (Goh, Pfeffer, \& Zenios, 2016), (Herath et al., } \\
\text { 2014), (Jenkins, Anderson, Vance, Kirwan, \& Eargle, 2016), (Jones, } \\
\text { Ravid, \& Rafaeli, 2004), (Kautz, Madsen, \& Nørbjerg, 2007), (Liang \& } \\
\text { Xue, 2009), (Lin, Fan, \& Chau, 2014), (Lin, Hsu, Cheng, \& Chiu, 2015), } \\
\text { (Nunamaker Jr., Derrick, Elkins, Burgoon, \& Patton, 2011), (Moody \& } \\
\text { Galletta, 2015), (Ortiz de Guinea \& Webster, 2013), (Ren, Kiesler, \& } \\
\text { Fussell, 2008), (Ridings \& Wasko, 2010), (Stein, Newell, Wagner, \& } \\
\text { Galliers, 2015), (Street \& Meister, 2004), (Sykes, Venkatesh, \& Gosain, }\end{array}$ & \\
\hline
\end{tabular}




\begin{tabular}{|c|c|}
\hline \multirow{3}{*}{$\begin{array}{l}\text { online } \\
\text { shopping } \\
\text { stress, coping } \\
\text { with social } \\
\text { support, coping } \\
\text { with fake } \\
\text { news) }\end{array}$} & $\begin{array}{l}\text { 2009), (Tu, Turel, Yuan, \& Archer, 2015), (Wall, Lowry, \& Barlow, 2016), } \\
\text { (Xiang Fang, Benamati, \& Lederer, 2011) }\end{array}$ \\
\hline & $\begin{array}{l}\text { Non-IS: (Alpass et al., 2004), (Barber \& Jenkins, 2014), (Collin-Jacques Non-IS: } 11 \\
\text { \& Smith, 2005), (Dalbokova, Tzenova, \& Ognjanova, 1995), (Dollard, } \\
\text { Skinner, Tuckey, \& Bailey, 2007), (Giumetti et al., 2013), (Greiner, } \\
\text { Ragland, Krause, Syme, \& Fisher, 1997), (Griffiths, 2002), (Lundberg, } \\
\text { 2015), (Markman \& Medin, 1995), (Paškvan, Kubicek, Prem, \& Korunka, } \\
\text { 2015) }\end{array}$ \\
\hline & Total: 38 \\
\hline & $\begin{array}{l}103 \text { IS articles rejected out of } 117 \text {, leaving } \mathbf{1 4} \text { IS articles } \\
57 \text { non-IS articles rejected out of } 65 \text {, leaving } 8 \text { non-IS articles } \\
\text { In total, } \mathbf{1 6 0} \text { articles rejected out of } 182 \text {, leaving } 22 \text { articles }\end{array}$ \\
\hline
\end{tabular}

*Note: The full list of references of removed articles is available from the authors. 


\begin{tabular}{|c|c|c|c|c|c|c|}
\hline Authors & $\begin{array}{l}\text { Technology } \\
\text { Environmental } \\
\text { conditions }\end{array}$ & $\begin{array}{l}\text { Techno- } \\
\text { Stressors }\end{array}$ & Outcomes & $\begin{array}{l}\text { Coping } \\
\text { response }\end{array}$ & $\begin{array}{l}\text { Moderators of } \\
\text { the of the } \\
\text { techno- } \\
\text { stressor- } \\
\text { outcome } \\
\text { relationship }\end{array}$ & Methods \\
\hline $\begin{array}{l}\text { Aiello, J. R., and Kolb, K. J. 1995. "Electronic Performance } \\
\text { Monitoring and Social Context: Impact on Productivity and } \\
\text { Stress," Journal of Applied Psychology (80:3), pp. 339-353. }\end{array}$ & & & $X$ & & & Experiment \\
\hline $\begin{array}{l}\text { Ayyagari, R., Grover, V., and Purvis, R. 2011. "Technostress: } \\
\text { Technological Antecedents and Implications," MIS Quarterly } \\
\text { (35:4), pp. 831-858. }\end{array}$ & $X$ & & $X$ & & & Survey \\
\hline $\begin{array}{l}\text { Barber, L. K., and Santuzzi, A. M. 2015. "Please Respond ASAP: } \\
\text { Workplace Telepressure and Employee Recovery," Journal of } \\
\text { Occupational Health Psychology (20:2), pp. 172-189. }\end{array}$ & & $X$ & $X$ & & & Survey \\
\hline $\begin{array}{l}\text { Barley, S. R., Meyerson, D. E., and Grodal, S. 2011. "E-mail as a } \\
\text { Source and Symbol of Stress," Organization Science (22:4), pp. } \\
887-906 .\end{array}$ & & $X$ & $X$ & & & $\begin{array}{l}\text { Survey, } \\
\text { Qualitative } \\
\text { Interviews }\end{array}$ \\
\hline $\begin{array}{l}\text { Beaudry, A., and Pinsonneault, A. 2005. "Understanding User } \\
\text { Responses to Information Technology: A Coping Model of User } \\
\text { Adaptation," MIS Quarterly (29:3), pp. 493-524. }\end{array}$ & & & & $x$ & & $\begin{array}{l}\text { Qualitative } \\
\text { Interviews }\end{array}$ \\
\hline $\begin{array}{l}\text { Brown, R., Duck, J., and Jimmieson, N. 2014. "E-mail in the } \\
\text { Workplace: The Role of Stress Appraisals and Normative } \\
\text { Response Pressure in the Relationship Between E-mail Stressors } \\
\text { and Employee Strain," International Journal of Stress } \\
\text { Management (21:4), pp. 325-347. }\end{array}$ & & & $X$ & & & Survey \\
\hline $\begin{array}{l}\text { Chen, S., Westman, M., and Eden, D. 2009. "Impact of enhanced } \\
\text { resources on anticipatory stress and adjustment to new } \\
\text { information technology: A field-experimental test of conservation } \\
\text { of resources theory," Journal of Occupational Health Psychology } \\
(14: 3), \text { pp. 219-230. }\end{array}$ & & $X$ & $X$ & & & Experiment \\
\hline $\begin{array}{l}\text { D’Arcy, J., Herath, T., and Shoss, M. K. 2014. "Understanding } \\
\text { Employee Responses to Stressful Information Security }\end{array}$ & & $X$ & $X$ & $X$ & & Survey \\
\hline
\end{tabular}




\begin{tabular}{|c|c|c|c|c|c|}
\hline $\begin{array}{l}\text { Requirements: A Coping Perspective," Journal of Management } \\
\text { Information Systems (31:2), pp. 285-318. }\end{array}$ & & & & & \\
\hline $\begin{array}{l}\text { Day, A., Paquet, S., Scott, N., and Hambley, L. 2012. "Perceived } \\
\text { information and communication technology (ICT) demands on } \\
\text { employee outcomes: The moderating effect of organizational ICT } \\
\text { support.," Journal of occupational health psychology (17:4), pp. } \\
\text { 473-491. }\end{array}$ & & $X$ & $X$ & & Survey \\
\hline $\begin{array}{l}\text { Fuglseth, A. M., and Sørebø, Ø. 2014. "The effects of } \\
\text { technostress within the context of employee use of ICT," } \\
\text { Computers in Human Behavior (40), pp. 161-170. }\end{array}$ & & & $X$ & & Survey \\
\hline $\begin{array}{l}\text { Galluch, P. S., Grover, V., and Thatcher, J. B. 2015. "Interrupting } \\
\text { the Workplace: Examining Stressors in an Information } \\
\text { Technology Context," Journal of the Association for Information } \\
\text { Systems (16:1), pp. 1-47. }\end{array}$ & $X$ & $x$ & $X$ & $X$ & Experiment \\
\hline $\begin{array}{l}\text { Korunka, C., and Vitouch, O. 1999. "Effects of the } \\
\text { implementation of information technology on employees' strain } \\
\text { and job satisfaction: a context-dependent approach," Work \& } \\
\text { Stress (13:4), pp. 341-363. }\end{array}$ & & $X$ & $x$ & & Survey \\
\hline $\begin{array}{l}\text { Maier, C., Laumer, S., Eckhardt, A., and Weitzel, T. } 2014 . \\
\text { "Giving too much social support: social overload on social } \\
\text { networking sites," European Journal of Information Systems } \\
(24: 5), \text { pp. 1-18. }\end{array}$ & & $x$ & $x$ & & Survey \\
\hline $\begin{array}{l}\text { Maier, C., Laumer, S., Weinert, C., and Weitzel, T. 2015. "The } \\
\text { effects of technostress and switching stress on discontinued use of } \\
\text { social networking services: A study of Facebook use," } \\
\text { Information Systems Journal (25:3), pp. 275-308. }\end{array}$ & & $x$ & $X$ & & Survey \\
\hline $\begin{array}{l}\text { Ortiz de Guinea, A. (2016). A pragmatic multi-method } \\
\text { investigation of discrepant technological events: Coping, } \\
\text { attributions, and 'accidental' learning. Information \& } \\
\text { Management, 53(6), 787-802. }\end{array}$ & & & & $x$ & $\begin{array}{c}\text { Survey, } \\
\text { Experiment }\end{array}$ \\
\hline $\begin{array}{l}\text { Ragu-Nathan, T. S., Tarafdar, M., Ragu-Nathan, B. S., and Qiang } \\
\text { Tu. 2008. "The Consequences of Technostress for End Users in } \\
\text { Organizations: Conceptual Development and Empirical } \\
\text { Validation," Information Systems Research (19:4), pp. 417-433. }\end{array}$ & & & $x$ & & Survey \\
\hline
\end{tabular}




\begin{tabular}{|c|c|c|c|c|}
\hline $\begin{array}{l}\text { Reinke, K., and Chamorro-Premuzic, T. 2014. "When email use } \\
\text { gets out of control: Understanding the relationship between } \\
\text { personality and email overload and their impact on burnout and } \\
\text { work engagement," Computers in Human Behavior (36), pp. 502- } \\
509 \text {. }\end{array}$ & $x$ & $X$ & & Survey \\
\hline $\begin{array}{l}\text { Soucek, R., and Moser, K. 2010. "Coping with information } \\
\text { overload in email communication: Evaluation of a training } \\
\text { intervention," Computers in Human Behavior (26:6), pp. 1458- } \\
1466 .\end{array}$ & & $X$ & $X$ & $\begin{array}{l}\text { Quasi- } \\
\text { experiment }\end{array}$ \\
\hline $\begin{array}{l}\text { Sprigg, C. A., and Jackson, P. R. 2006. "Call Centers as Lean } \\
\text { Service Environments: Job-Related Strain and the Mediating Role } \\
\text { of Work Design," Journal of Occupational Health Psychology } \\
(11: 2) \text {, pp. 197-212. }\end{array}$ & $X$ & $X$ & & Survey \\
\hline $\begin{array}{l}\text { Srivastava, S. C., Chandra, S., and Shirish, A. } 2015 . \\
\text { "Technostress creators and job outcomes: theorising the } \\
\text { moderating influence of personality traits," Information Systems } \\
\text { Journal (25:4), pp. 355-401. }\end{array}$ & & $X$ & $X$ & Survey \\
\hline $\begin{array}{l}\text { Sykes, T. A. 2015. "Support Structures and Their Impacts on } \\
\text { Employee Outcomes: A Longitudinal Field Study of an Enterprise } \\
\text { System Implementation,” MIS Quarterly (39:2), pp. 473-A11. }\end{array}$ & & $X$ & & Survey \\
\hline $\begin{array}{l}\text { Tams, S., Hill, K., de Guinea, A. O., Thatcher, J., and Grover, V. } \\
\text { 2014. "NeuroIS-Alternative or Complement to Existing } \\
\text { Methods? Illustrating the Holistic Effects of Neuroscience and } \\
\text { Self-Reported Data in the Context of Technostress Research," } \\
\text { Journal of the Association for Information Systems (15:10), pp. } \\
\text { 723-753. }\end{array}$ & & $X$ & & Experiment \\
\hline $\begin{array}{l}\text { Tarafdar, M., Qiang Tu, Ragu-Nathan, B. S., and Ragu-Nathan, T. } \\
\text { S. 2007. "The Impact of Technostress on Role Stress and } \\
\text { Productivity," Journal of Management Information Systems } \\
(24: 1) \text {, pp. 301-328. }\end{array}$ & $x$ & $x$ & & Survey \\
\hline $\begin{array}{l}\text { Tarafdar, M., Tu, Q., and Ragu-Nathan, T. S. 2010. "Impact of } \\
\text { Technostress on End-User Satisfaction and Performance," } \\
\text { Journal of Management Information Systems (27:3), pp. 303-334. }\end{array}$ & $X$ & $X$ & & Survey \\
\hline $\begin{array}{l}\text { Tarafdar, M., Pullins, E. B., and Ragu-Nathan, T. S. } 2015 . \\
\text { "Technostress: negative effect on performance and possible }\end{array}$ & & & $x$ & Survey \\
\hline
\end{tabular}




\begin{tabular}{|c|c|c|c|}
\hline mitigations," Information Systems Journal (25:2), pp. 103-132. & & & \\
\hline
\end{tabular}

